\title{
Benchmarking the scientific research on wastewater-energy nexus by using bibliometric analysis
}

\author{
Tianlong Zheng ${ }^{1}$ (D) $\cdot$ Pengyu Li ${ }^{1,2} \cdot$ Zhining Shi $^{3} \cdot$ Jianguo Liu $^{4}$
}

Received: 31 July 2017 / Accepted: 6 November 2017 /Published online: 13 November 2017

(C) Springer-Verlag GmbH Germany, part of Springer Nature 2017

\begin{abstract}
With an exponential increase in urbanization and industrialization, water pollution is an inevitable consequence of relatively lagging wastewater treatment facilities. The conventional activated sludge process for wastewater treatment primarily emphasizes the removal of harmful substances to maintain increasingly stringent effluent discharged standards, which is considered an energy-intensive technique. Therefore, innovative and sustainable wastewater treatment should pay
\end{abstract}

Tianlong Zheng and Pengyu Li made equal contribution.

Responsible editor: Philippe Garrigues

Electronic supplementary material The online version of this article (https://doi.org/10.1007/s11356-017-0696-5) contains supplementary material, which is available to authorized users.

Tianlong Zheng

tlzheng@ rcees.ac.cn

Pengyu Li

pyli_st@rcees.ac.cn

Zhining Shi

zhining.shi.career@gmail.com

Jianguo Liu

jgliu_yxc@163.com

1 Research Center for Eco-Environmental Sciences, Chinese Academy of Sciences, 18 Shuangqing Road, Haidian District, Beijing 100085, China

2 University of Chinese Academy of Sciences, 19(A) Yuquan Road, Shijingshan District, Beijing 100049, China

3 School of Chemical Engineering, The University of Adelaide, Adelaide, South Australia 5005, Australia

4 College of Energy and Power Engineering, Inner Mongolia University of Technology, 49 Aiminjie, Xincheng District, Hohhot, Inner Mongolia 010051, China more attention to energy and resource recovery in dealing with fossil fuel depletion, global-scale energy security, and climate change. A bibliometric analysis was applied to trace wastewater-energy nexus-related research during the period 1991 to 2015, with respect to the Science Citation Index EXPANDED (SCI-EXPANDED) database. Journal of Hazardous Materials, ranking 1st in $h$-index (79), was the most productive journal $(431,4.5 \%)$ during the same time, followed by International Journal of Hydrogen Energy $(422,4.4 \%)$ and Water Research $(393,4.1 \%)$ journal, the latter owning a topmost journal impact factor. Though, China $(2154,22.5 \%)$ was the most productive country, while the USA with highest $h$-index (88) was the favorest collaborative country. The Chinese Academy of Sciences, China (241, $2.5 \%$ ) produced the maximum publications. A novel method called "word cluster analysis" showed that the emerging sustainable processes and novel renewable energy application are applied in response to the desire for a net wastewater-energy nexus system. Based on different wastewater types, the emerging energy and sources recovery treatment processes of Anammox, anaerobic digestion, and microbial fuel cells gained extensive innovation. Evaluation indicators including sustainability, life cycle assessment, and environmental impact were appropriately used to dissert feasibility of the novel treatment methods in regard of renewable energy utilization, energy savings, and energy recovery. The transformation of the new concept of "broaden income source, economize on expenditures and exploit inner potential" should be generalized in order to achieve an environmentally sustainable development of wastewater-energy nexus system.

Keywords Bibliometric analysis - Energy recovery · Resource recovery · SCI-EXPANDED · Wastewater-energy nexus 


\section{Introduction}

Rapid urbanization and industrialization during the nineteenth century led to serious environmental issues and widespread epidemic diseases (van Loosdrecht and Brdjanovic 2014), especially by the indiscriminate discharge of wastewater via unsustainable pathways. In response, wastewater treatment and sanitation techniques have made great progress in dealing with the increasingly urgent demand for environmental protection. The activated sludge process, as the core of the current biological wastewater treatment technique, has been employed for more than 100 years (Liu et al. 2015). However, the activated sludge process, which has always been considered as highly energy-intensive, causing solid waste production, and producing high levels of greenhouse gas emissions, cannot satisfy fast population growth, nor the requirement for a more environmentally sustainable world (Wang et al. 2015). Even more damning is the concept of the conventional technique, which emphasizes removal of harmful substances from wastewater to confront more and more stringent effluent discharged standard without any consideration of energy or resource recycle (Verstraete et al. 2009). Therefore, the innovative development of wastewater treatment has evolved over time, and is pushed further forward by our society's increasing expectations ( $\mathrm{Li}$ et al. 2014). The future sustainable wastewater treatment should be extremely focused on recovery of both energy and resources via the bioconversion processes in dealing with fossil fuel depletion, global-scale energy security, and climate change (Blanco et al. 2009; Li and Yu 2011; McCarty et al. 2011). The novel concept called "broaden income source, economize on expenditures and exploit inner potential" should take practice based on the following three perspectives during net wastewaterenergy nexus system: (i) renewable energy-derived wastewater treatment technique; (ii) efficient and economized wastewater reclamation process; (iii) potential bioenergy and resource recovery of wastewater.

(i) Broaden income source: It is well known that conventional activated sludge process is an energy-negative method for wastewater treatment. Therefore, the sources of energy should be broadened, of which the solar energy would be an optimal alternative for prospective energy needs due to its characteristic in environmentally friendliness, applicability, economic cost-saving, capability, and effectiveness (Kannan and Vakeesan 2016). Presently, solardriven wastewater treatment processes have been must more common worldwide in comparison to wind energy-driven wastewater treatment. The solar-driven wastewater treatment technique primarily focused through three pathways of solar-thermal conversion, photovoltaic, and photochemical transformations. The solarthermal-driven wastewater treatment process acts to pre- heat and maintain warm temperatures of wastewater, maintaining a high degradation performance in cold and solar energy-rich regions (Yiannopoulos et al. 2008); The photovoltaic-driven wastewater treatment process is a relatively mature technique, which first convert incident solar irradiation into electricity with photovoltaic panels and then self-supplied the energy consumption during the wastewater treatment process (Cho et al. 2014). The photovoltaic energy was mainly interconnected with power grid in large-scale wastewater treatment plant and stored in accumulator in middle- and small-scale sewage treatment plant respectively. Presently, the supply of photovoltaic energy without an accumulator is attractive due to the ease of maintenance and reduced environmental risk from not requiring large batteries; The photochemical-driven wastewater treatment technique is primarily based on photocatalytic oxidation process, which is always applied to eliminate and mineralize organic contaminants (especially for refractory and persistent toxic compounds) by exploiting the high reactivity of hydroxyl radicals (Malato et al. 2002). It is well recognized that wind energy, because of its characteristic in great instability, is rarely applied for wastewater treatment. Currently, the emerging and compatible wind-solar hybrid power supply system (Barton and Infield 2006) is useful for its reliability and marketability in areas with abundant resource of wind and solar energy, or areas with scant electrical infrastructure. Hobus and Hegemann (2003) discussed that the utilization of renewable energy with wind-solar hybrid for aeration of wastewater ponds is a serviceable alternative for improving seriously polluted ponds, and also for the construction of new wastewater ponds. Manju and Sagar (2017) also reported wind-solar energy is an interesting option for aeration of industrial wastewater in aerated lagoon, of which the aeration process is beneficial for the metabolism of aerobic organisms to degrade the organic matter into inorganic and stable solids.

(ii) Efficient and economized wastewater reclamation process: Underneath the new concept, the novel wastewater treatment technique cannot only focus on the totally organic removal to meet the effluent discharge standards but also take care of further recycling of organic carbon and nutrients. Presently, various kinds of fewer energy demand, or even energy-positive and enhanced resource recovery method are being developed to facilitate sustainable wastewater treatment around the world (Andrews et al. 2016; Shoener et al. 2014). As representative techniques, Anammox, anaerobic digestion (AD), and microbial fuel cells (MFC) are being explored to cut energy consumption and enhance resource recovery during wastewater reusing. Anammox, without an external carbon resource, could transfer ammonia to nitrogen gas 
by a synergistic effect of ammonia oxidation bacteria and Anammox bacteria (Zheng et al. 2017), which significantly reduce the aeration energy cost due to its lessened necessity of oxygen during the entire process. Anammox places emphasis on nitrogen removal of wastewater; therefore, pre-recycling of organic carbon should address people's attention in respect to its characteristic of noncarbon source addition and less dissolved demand. Preadsorption, especially by the activated sludge produce in sewage treatment plant, will be an ideal alternative to concentrate the organic substances. Activated sludge, found as a rapid adsorption and aggregation capacity in a short time, could be seamlessly transitioned for anaerobic fermentation. Of course, AD also could independently play the pretreatment role in matching Anammox process, of which organic compounds were first utilized to generate a valuable resource in the form of methane- or hydrogen-containing biogas; compared with AD, MFC could directly capture electricity power from organic component without less offsetting energy expenditure (Sun et al. 2016). Recently, MFC have been applied for the treatment of low-strength domestic wastewater, where there was a momentarily limited-domain for AD. However, MFC (Andrews et al. 2016) still need to be practically certified in its current efficiency and design of electrodes, application to wastewater, scale up, favorable long-term operation, and exploration of low-voltage to be competitive with AD process.

(iii) Potential bioenergy and resource recovery of wastewater: According to calculations, the potential energy theoretically existed in municipal wastewater is five times that which would be needed for the activated sludge process (Liu et al. 2015). Therefore, the valuable organics and nutrients from wastewater should be properly recovered to make up for the handling cost for wastewater disposal (Hülsen et al. 2014). Biogas, hydrogen, and biodiesel are the three most commonly renewable forms for resource recovery from wastewater. Biogas, produced by AD process, is widely applied as a burned gas or to produce electricity in rural region. The biohydrogen technique is always considered as a lowcost, energy-saving, and environmental-friendly technique, which has been applied as a clean source of hydrogen with a high conversion efficiency, recyclability, and nonpolluting nature from various kinds of wastewater including agricultural, municipal, and livestock wastewater. Biodiesel, defined as a green renewable, biodegradable, and non-toxic energy sources, revealed a close relationship with algae and microalgae during wastewater treatment. Microalgae culture, one of most promising energy-positive methods, could alter the conventional nitrogen and phosphate removal process to achieve nutrient recovery, as well as carbon sequestration via photosynthesis (Batstone et al. 2015). Therefore, the recognition of wastewater as a recycling source may realize energy-positive treatment and achieve a sustainable balance in wastewater treatment and energy consumption (Shoener et al. 2014).

In the current work, a holistic bibliometric analysis was undertaken to determine tendency in wastewater-energy nexus research during the period spanning 1991 to 2015. To undertake this analysis, the following categories of information were analyzed to probe publication patterns: document type, languages, categories of articles, journals in previously published articles, the countries and territories from which the publications emerged, the institutions who had published the articles, and $h$-index. Then, research was conducted utilizing global trends and hotspots, which entailed using "distributed author keywords" throughout different periods as well as a "word cluster analysis" (Mao et al. 2010). Finally, a novel wastewater-energy nexus concept has been put forward to achieve net wastewater-energy nexus system. Our results outline a framework for an insightful recognition of current wastewater-energy nexus research and as a result of a constructive advice for decision makers.

\section{Data acquisition and methods}

\section{Data acquisition}

The methodology adopted for data acquisition and analysis in the current study was similar to that adopted in other bibliometric studies (Chiu et al. 2004; Fu et al. 2013). Bibliometric data were got from SCI-EXPANDED database and 2016 Journal Citation Reports (JCR) Science Edition of Thomson Reuters, on 25 of October, 2016. The 2016 JCR covers 11,365 journals across 234 scientific disciplines spanning 81 countries. (wastewater* OR "waste-water*") and (energy OR energies) were designated as core themes into SCIEXPANED during the period 1991 to 2015.

\section{Data analysis}

The aforementioned categories across which searches were undertaken, namely languages, document types, subject categories, outputs, journals, countries, institutions, abstracts, author keywords, keywords plus, titles, and $h$-index, were analyzed in Microsoft Excel 2013 (Katz 1997). BibExcel 1.0.0.0 was used to conduct a frequency and co-occurrence analysis (Persson et al. 2009). Pajek 1.0.0.1 was used to generate network diagram for cooperation analysis (De Nooy et al. 2011). The contribution offered by various countries and institutes was determined through affiliation with no less than one author of each published articles. Article originating from Hong 
Kong was grouped under China (Chuang et al. 2011). Publications owning to Reunion were included in France (Fu and Ho 2016). Publications originating from England, Northern Ireland, Scotland, and Wales were included in the UK (Zhang et al. 2010). In addition, Czechoslovakia and the Czech Republic were both classified as the Czech Republic (Fu and Ho 2016).

"Internationally collaborative publication" belonged to publications published by researchers from multiple countries, whereas "independent type" was defined as those papers where all research workers' addresses were from same countries. "Single institute publication" was defined as being when all researchers' addresses on a publication were from the identical institute. "Inter-institutionally collaborative publication" belonged to papers with researchers under multiple institutions (Fu et al. 2012). $h$-index was regarded as the $\mathrm{h}$ of $\mathrm{Np}$ articles were cited no less than $\mathrm{h}$ times each and the other (Nph) articles were cited no more than $\mathrm{h}$ times each. The journal impact factor (JIF) and JIF quartile were also derived from JCR 2016.

\section{Results and discussion}

\section{Publication pattern}

\section{Document type and language of publication}

There are 11,283 publications in the field of wastewaterenergy nexus study recording in SCI-EXPANDED during the period 1991 to 2015, which were made up of ten kinds of document types. Articles comprised the vast majority of document types, representing $85.3 \%$, or 9626 , of the total. The remaining publications were spread across a number of categories; namely proceedings papers (838), reviews (766), editorial materials (19), meeting abstracts (12), book chapters (11), notes (5), news items (3), letters (2), and corrections (1).

As articles represented the core category of all kinds of documents, the remaining types were not utilized in next steps. The numbers of articles written in English were 9626 (98.2\%). This was followed by German (37), Polish (32), Chinese (31), Spanish (24), Portuguese (12), Croatian (7), French (6), Japanese (6), Turkish (3), Korean (3), Finnish (2), Serbo-Croatian (2), and one each in Czech, Russian, Romanian, and Malay.

\section{Publication outputs}

With no abstracts in SCI-EXPANDED for articles published prior at 1991 (Ho et al. 2010), the terms (wastewater* OR "waste-water*") and (energy OR energies) were adopted as topic search phrases to explore their tendency. The earliest article was found in SCI-EXPANDED on wastewater-energy nexus study published in 1974. Figure 1 reveals that the quantity of wastewater-energy nexus-related research remained stable from 1974 to 1990 and then slow increased during the period 1991 to 2006. Annual publication numbers rose greatly from 2007.

From 1991 to 2015, the quantity of articles grew from 27 to 1605. An exponential model expresses the cumulative quantiy of articles per year since 1991 (Fig. 2) based on an equation $\mathrm{C}=-41.24+70.59 \mathrm{e}^{0.20 \mathrm{Y}}\left(R^{2}>0.999\right)$, where $\mathrm{Y}$ represented the quantiy of years since 1991 and $C$ represented the cumulative quantiy of publications. The quantity of articles reported in 2018 (3163) is modeled to be nearly twice than that of 2015 (1605).

Appendix Table 1 of the supporting information demonstrates that the average amount of authors each paper has grown by $86 \%$, from 2.5 in 1991 to 4.6 in 2015, exhibiting a alike $40 \%$ increase in the quantity of institutes each publication during that identical timespan. The average quantity of countries reached a stable level of 1.2 for each paper. The average quantity of references cited per paper significantly grew by $242 \%$. The quantity of times cited each paper peaked at 57.3 citations in 2005 . The quantity of authors each paper has was most frequently three, accounting for 2188 articles (22.7\%). Articles with two to five authors were represented by 7322 articles $(76.1 \%)$ and 349 articles (3.6\%) had one author. The author frequency distribution proportion in the current study was similar to a previous published bibliometric study for industrial wastewaterrelated research (Zheng et al. 2015d).

The two most cited publications were each cited over 850 times. The most cited article with 996 citations is 'Hydrogen production by biological processes: a survey of literature (Das and Veziroğlu 2001)" published in Inter. J. Hydrogen Energ. in 2001 from Indian Inst Technol, India, which reported that the fermentative hydrogen production process was the most promising technique by comparison to other biological hydrogenation processes. The second most cited article "Electricity

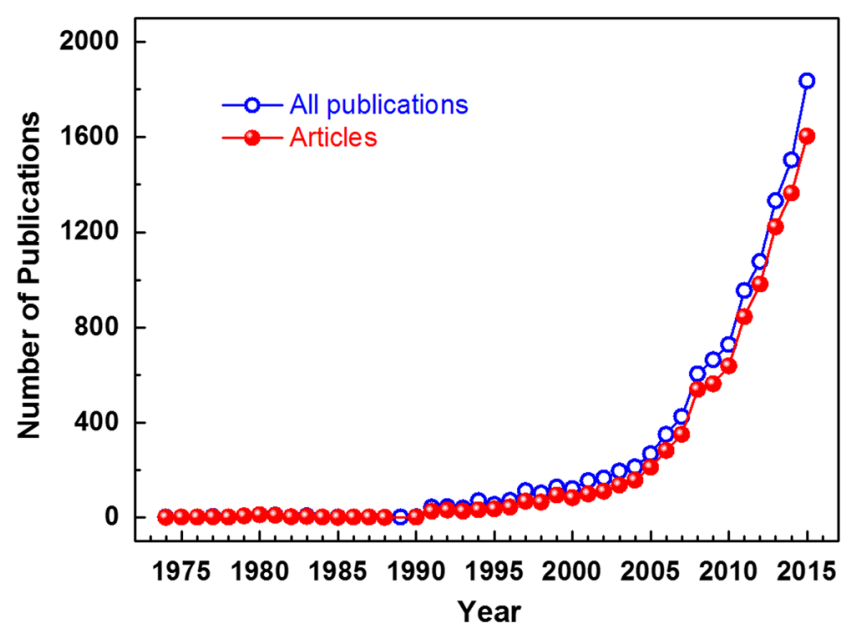

Fig. 1 Growth tendency of SCI-EXPANDED publications on wastewater-energy nexus research over the last 40 years 


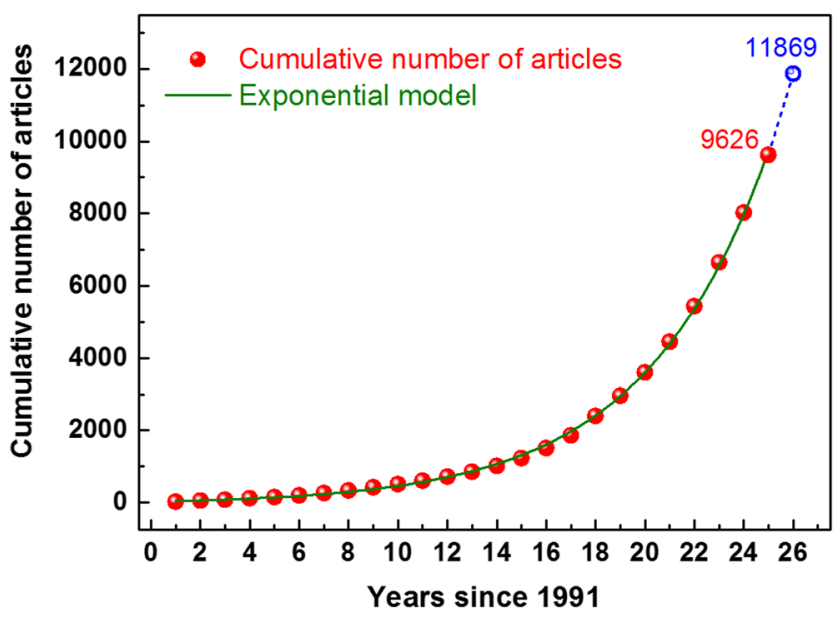

Fig. 2 The variation of cumulative number of articles followed with the years since 1991

generation using an air-cathode single chamber microbial fuel cell in the presence and absence of a proton exchange membrane (Liu and Logan 2004)" with 853 citations was reported in Environ. Sci. Technol. in 2004 from Penn State Univ, USA. In addition, the most cited article per year of 131 times, likewise the 3rd most cited articles with 783 citations, was "An orthophosphate semiconductor with photooxidation properties under visible-light irradiation (Yi et al. 2010)" published in Nat. Mater. in 2004 from Natl Inst Mat Sci, Japan, which derived a potential photofunctional material $\left(\mathrm{Ag}_{3} \mathrm{PO}_{4}\right.$ semiconductor) for both water splitting and wastewater elimination during solar-energy application.

\section{Article performance: subject category and journal}

The 9626 articles featured in 1085 journals spanned across 73 SCI-EXPANDED subject categories. Among these journals, 921 (84.9\%) contained no more than nine articles. The performance of top 20 journals (TA $>70)$ with subject categories, rankings of journals in their categories, $h$-index, JIF, $h$-index/ $\mathrm{TA}$, and countries are visible supporting information Appendix Table 2. These journals accounted for approximately $43.5 \%$ of all articles.

$J$. Hazard. Mater, ranking 1 st in $h$-index (79), published the greatest quantities of papers $(431 ; 4.5 \%)$, followed by Inter. $J$. Hydrogen Energ. (422; 4.4\%), Water Res. (393; 4.1\%), and Bioresource Technol. $(374 ; 3.9 \%)$. Whereas, Water Res. ranked 1 st in JIF (5.591), 2nd in $h$-index (63) in 2015, and 1st in water resources (Q1: 1/85). Of the top 20 journals, 8 are from the UK, 5 are from the Netherlands, 4 are from the USA, and 1 is from each of Italy, Germany, and Switzerland.

With journals owning several subject categories, wastewater-energy nexus-related literature crossed 73 SCIEXPANDED categories. Figure 3 revealed that, with regard of the increasing quantity of articles of each category, wastewater-energy nexus-related literature evidenced a quite

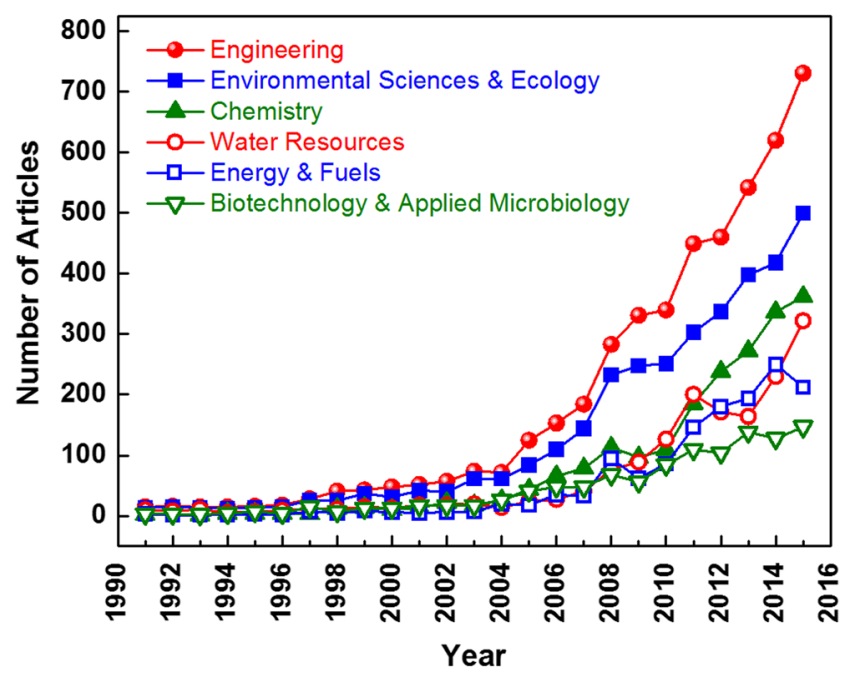

Fig. 3 Growth tendency of six most productive subject categories (TA > 1100)

similar tendency to those run over various scientific fields during new century. "Engineering" and "Environmental Sciences \& Ecology" were the dominated two, then "Chemistry."

Of the 1085 journals that published the 9626 articles, 486 (44.8\%) journals only included one article, 162 (14.9\%) journals include two papers, and $95(8.8 \%)$ journals included three articles. Approximately 2252 (23.4\%) were published on top six journals. The publication tendency of top six journals was revealed in Fig. 4.

\section{Output in institutes and countries}

Contributions made by various countries were determined through examining the affiliation with no less than one author for each publication. There are 9626 articles including author's address information from 1991 and 2015, spanning 109 countries/territories. Of them, 7647 (79.8\%) comprised independent articles and 1941 (20.2\%) called international collaboration articles. The 20 most productive countries were revealed in detail (Shown in supporting information Appendix Table 3). The top 20 productive countries distributed in eight Asian countries/territories, six European countries, four American countries, and one in each Africa and Oceania, which contributed $78.7 \%$ of whole papers. The seven primary developed countries (generally called G7), occupied into top 16 , making $26.4 \%$ of total articles. Developed countries occupy a leading position during wastewater-energy nexus study (Bell and Pavitt 1997). However, China, India, and Brazil were together found to be productive with 3342 (28.2\%) of the total articles, the emerging inter-organizational BRICS countries $(3420,28.9 \%)$ also play an increasingly important role during wastewater-energy nexus-related field (Finardi 2015).

China, owning 2nd ranking in $h$-index (77), was 1 st in total number of articles (2154) and independent articles (1673). Whereas, China was 17th $(22.33 \%)$ out of 20 countries in respect of collaborative strength with external research. 
(a)

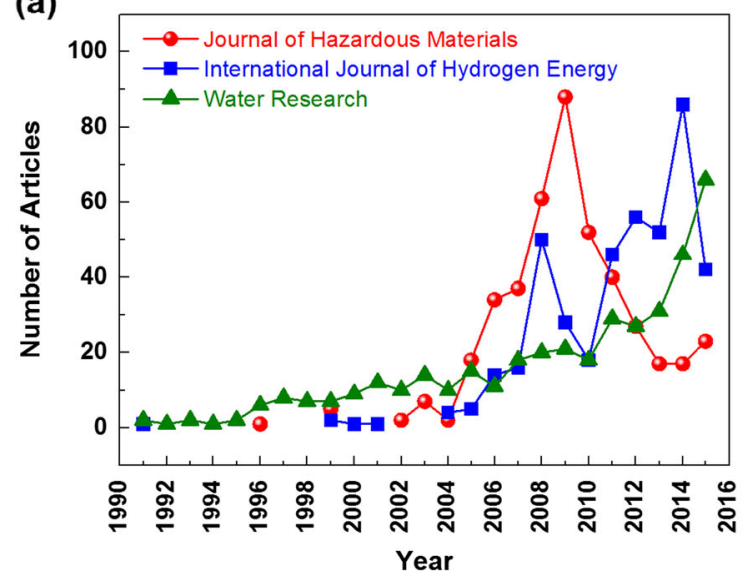

Fig. 4 Growth tendency of six most productive journals (TA > 300)

France comparatively ranked 14th in total articles yet owned the highest collaborative strength of $58.54 \%$. The collaborative strength of authors during top 20 countries revealed apparent difference. Nonetheless, the USA, with 1 st $h$-index of 88 , dedicated the 1st collaborative strength (523) with five collaborators (Appendix Table 3 of supporting information), showing the USA's overwhelming dominance in the current field (Zheng et al. 2015d). Also, international collaborative strength has been strengthened, which is similar to other fields (Niu et al. 2014; Yu et al. 2016). In order to capture important data in respect of international cooperation, 32 countries which produced no fewer than eight articles were selected as research sample. These samples were first gathered in BibExcel and analyzed in Persson (1994). The output cluster was drawn by Pajek (Fig. 5). The size of circles and weight of lines represented total quantity of papers published by their countries and collaborative strength among different countries, respectively [24]. (b)

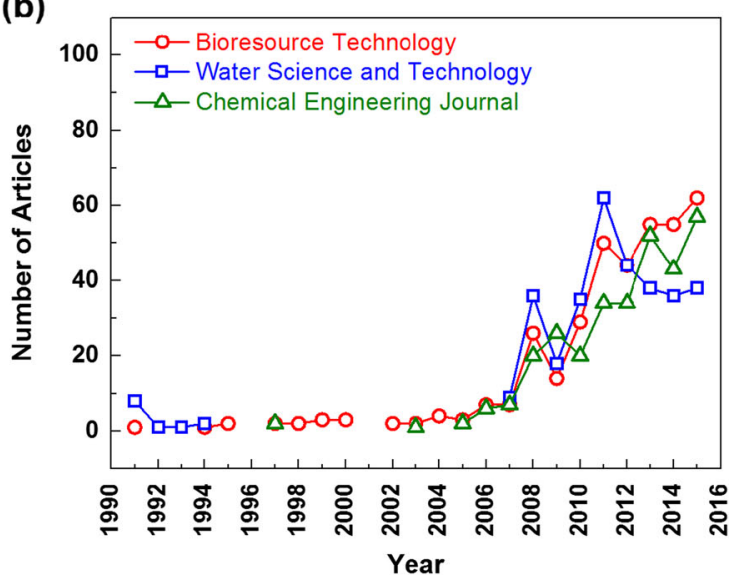

Figure 5 shows that the China-USA collaborations with 178 was the closest ties during the collaboration network, distantly followed by USA-South Korea (71), ChinaAustralia (61), China-Japan (45), and USA-Canada (40). This result is also accorded with the published paper from other field (Yataganbaba et al. 2017). In addition, the top three most centralized groups, which happen to be top three productive countries, were USA (20), China (14), and Spain (12). Interestingly, the collaborating countries are characteristically distributed in geography, which is consistent with the conclusion in other scientific disciplines (Gao et al. 2015; Gao and Guo 2014). Further, the relative ranking of countries that placed higher in respect of the degree of academic cooperation with other countries was also determined (Mao et al. 2015a; Zheng et al. 2016a).

The China (2154) and USA (1356) produce the most articles during the period 1991 to 2015 , accounting for 22.5 and $14.1 \%$, respectively. The other countries published no more
Fig. 5 The cooperation network diagram among countries with at least eight articles

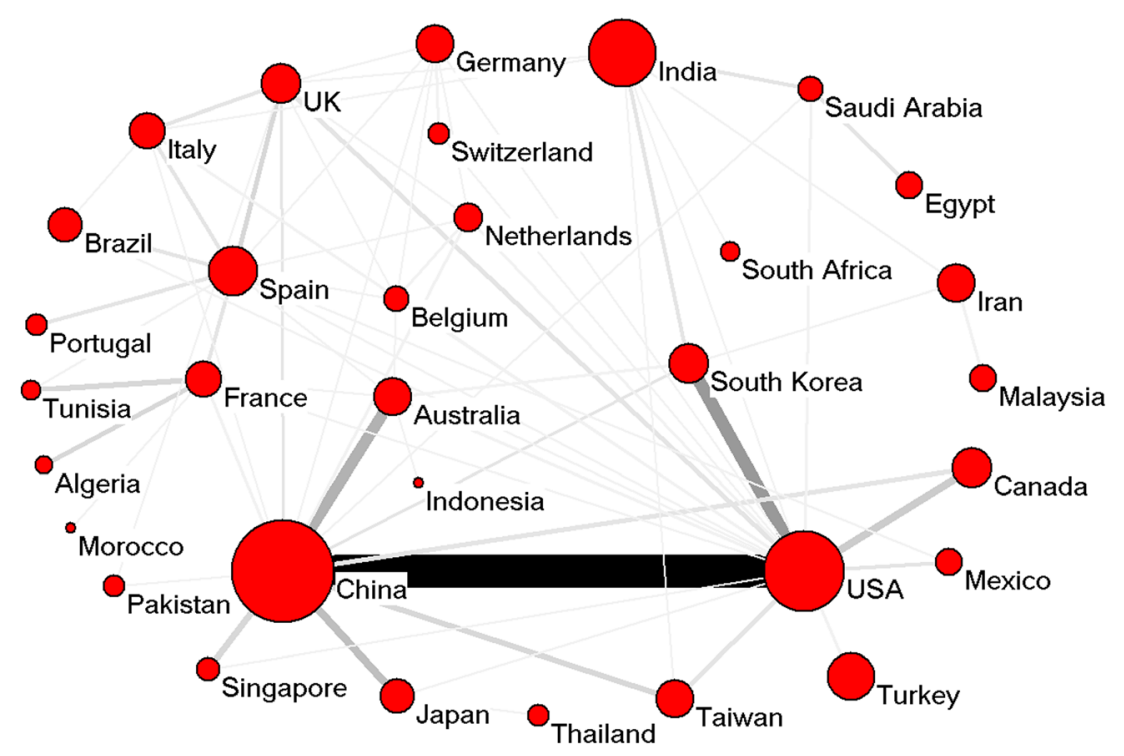


than 1000 articles. The tendency of China and USA in producing article is presented in Fig. 6.

The USA always ranked first each year before 2004 (Fig. 6). The quantity of articles per year in China as well as the difference in value between China and USA significantly increased since 2005. The result showed that the USA has a much earlier academic history in respect of the wastewaterenergy nexus-related research field. The first article produced by USA is in 1974 (Wylie 1974), and 1987 for China (Chen and Yan 1987). Whereas, since then, China has experienced a sharp growth rate in published papers quantity of last 10 years, with China exceeding the number of those published by the USA since 2006, which can be attributed to the rapid development of China's economy, increasing investments in scientific research, and raising consciousness in environmental necessity on account of low impact assessment and energysaving in dealing with wastewater issues (Liu et al. 2013; Lo 2014; Yi et al. 2010; Zhou and Leydesdorff 2006). Figure 6 revealed a big difference among the two countries on account of total quantity of citations each year during the period 1991 to 2005. Though the USA was not just quantitative but qualitative of scientific articles, China has significantly minified the difference in the last 10 years, which should be attributed to positive decision-making by Chinese government (King 2004; Yi et al. 2010).

At the institutional level, 9626 articles were published by 5452 institutes across 109 countries; 4977 (52\%) were the articles of inter-institutional collaboration, while 4611 (48\%) were considered independent. The collaborative strength among institutes is $31.7 \%$ more than that among countries. The top 20 productive institutes are distributed in eight institutes from China, two each from India and Taiwan, and one each from Australia, Belgium, Brazil, Iran, Netherlands, Singapore, Spain, and USA (Shown in Appendix Table 4 of supporting information), which reflects continuously increasing academic capacity of institutions in China.

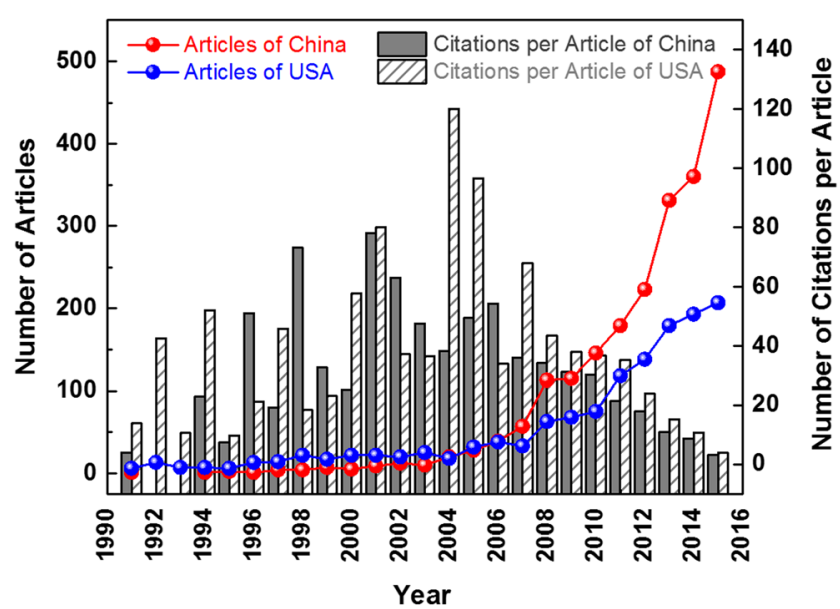

Fig. 6 The current tendency of articles and citations between China and USA from 1991 to 2015 (TA > 1300)
The Chinese Academy of Sciences, China, owning 2nd ranking in $h$-index of 36 , ranked 1st during all kinds of article rankings including total quantity (241), inter-institutional collaboration (188), first authors (139), and the authors for correspondence (129), which should not be attributed to it multiply branches in China (Chen and Ho 2015; Sun et al. 2012), but due to its global leadership role during technological innovation, scientific discovery, and aspiring minds (Nature Index 2014). Harbin Inst Technol, China (176), Indian Inst Technol, India (152), and Tongji Univ, China (96), ranked from 2 to 4 respectively. With respect of the similarly lower percentage of inter-institutionally collaborative institutions in Indian Inst Technol, India (20th, 46.71\%) and Penn State Univ, USA (19th, 49.25\%), how about the quality of publications during wastewater-energy nexus-related research? The Indian Inst Technol, India, owning 2 nd ranking in $h$-index (36) as well as 3rd ranking in outputs, occupied 14th ranking of 20 in $h$ index/TA (23.68\%); on the contrary, the Penn State Univ, USA, owning a 1st ranking in $h$-index of 37 and 13rd ranking outputs (67), occupied 1st ranking in $h$-index/TA (55.22\%). One common problem was revealed, whereby institutions in developed countries tend to focus more on quality of publications and the institutions in developing countries pay more attention to the quantity of publications. This could be generally attributable to the relatively lower percentage of scientific activities in their Gross Domestic Product (GDP) of developing countries (Salager-Meyer 2008; Sharma and Thomas 2008).

Collaborations play increasing role during wastewaterenergy nexus-related research. Of 9588 articles containing address information, 4611 (48\%), 3036 (32\%), and 1941 (20\%) were considered as independent, national, and international collaborations, respectively. Further, the internationally collaborative strength significantly increased, from 4\% in 1991 to $23 \%$ in 2015 , which could be attributed to the increasing tendency for institutes and countries to engage in wastewaterenergy nexus-related research (Zheng et al. 2016a).

\section{Current tendency and hotspots}

\section{Performance of author keywords}

The author keywords, title, abstract, and keywords plus of articles can be statistically analyzed to determine the prospective development, which has been certified as a useful tool on comprehending the further step of scientific research. The research tendency for author keywords was always analyzed under different time quantum (Fu et al. 2014; Tan et al. 2014; Xie et al. 2008; Zhang et al. 2016, 2017). Excluding 1427 articles without author keywords information, the others (8199) were explored. This resulted 17,060 keywords listed by authors; however, 13,040 (76.4\%) keywords were used only once, which showed that most of keywords emphasized depth and breadth of research (Hou et al. 2015; Li and Zhao 
2015). Only 510 (2.9\%) of keywords were utilized no less than ten times, which also indicated the diversifications of scientific study. The hotspot could be derived from the ranking variation of author keywords during five 5-year time quantum. Appendix Table 5 of supporting information showed the tendency of top 30 author keywords. In addition, the network diagram among these keywords was also displayed by Pajek (Fig. 7).

The most common utilized author keywords of "wastewater(s)" and "energy" were disregarded, which were regarded as topic words in the current study, Fig. 7 and Appendix Table 5 of supporting information show that the three most common used author keywords are "Adsorption" (677; $8.3 \%)$, "Wastewater Treatment" (607; 7.4\%), and "Kinetic(s)" $(512 ; 6.2 \%)$, which revealed that the adsorption is a feasible and effective method for wastewater treatment, including dye, heavy metal, and phenol (Barakat 2011; Hamdaoui and Naffrechoux 2007; Yagub et al. 2014). Figure 7 shows that the biosorption, regarded as a novel bioremediation technique, is a beneficial supplement for present adsorption process (Aksu 2005), which are becoming increasingly popular due to its environmentally friendly and low-cost bioadsorbent; moving up in rankings from not available in 1991-1995 to 9th in 20062010. "Thermodynamics" and "Isotherm(s)" attracted worldwide focus from both not available in 1991-1995 to 6th and 8th in 2011-2015, respectively, revealing a desire necessary for seeking the internal mechanism of the treatment method (Foo and Hameed 2010; Liu and Liu 2008).

With exception of the conventional wastewater treatment process, the others three top 30 most common used author keywords, such as "Microbial Fuel Cell (MFC)" (356; 4.2\%), "Anaerobic Digestion (AD)" $(228 ; 2.8 \%)$, and "Photocatalysis" $(165 ; 2.0 \%)$, also attract ongoing concern due to their electrical energy generation (Du et al. 2007; Logan and Regan 2006), potential energy recovery (Batstone and Virdis 2014; Smith et al. 2014), and renewable energy utilization (Prieto-Rodriguez et al. 2012; Qu et al. 2013). MFC, which could transform biochemical into electrical energy, was a potential technique for simultaneous wastewater treatment and renewable energy recovery (Logan and Regan 2006). AD was used to be a conventional biological process for the bioconversion of organic matter; however, the wastewater nutrient and energy recovery was the sensibly bright future of $\mathrm{AD}$ followed by the emerging techniques and new concept (Batstone and Virdis 2014). Photocatalysis, one looked forward to serving as a cost-saving, environmentally friendly, and sustainable technique, was pursuing a large-scale application for the renewable energy sources of solar energy (Chong et al. 2010). Inevitably, deemed to be the most suitable catalysts for photocatalysis process (Li et al. 2003), "Titanium Dioxide $\left(\mathrm{TiO}_{2}\right)$ " $(100 ; 1.2 \%)$ possesses an intimate connection with "Photocatalysis" (shown in Fig. 7), which ranked 27th in author keywords (shown in Appendix Table 5 of supporting information). "Biogas" $(179 ; 2.2 \%)$ and "Biohydrogen" $(154 ; 1.9 \%)$ ranked in top 15 , moving up in the rankings from both not available in 1991-1995, 20th and not available in 1996-2000, 11th and 170th in 2001-2005, 12th and 10th in 2006-2010, and 10th and 13 in 2011-2015, respectively. The increasing tendency of biogas and biohydrogen on wastewater-energy nexus-related research revealed an intriguing interest of scientists and engineering in pursing the substitution mission of fossil energy (Ball and Wietschel 2009; Weiland 2010). "Electrocoagulation" (232; 2.8\%) (Chen 2004), "Membrane Bioreactor" (129; 1.6\%) (Le-Clech et al. 2006), and "Advanced Oxidation Process (AOP)" (104; 1.3\%) (Parsons 2005) ranked in top 51 among all five 5-year time quantum, which showed that various wastewater treatment methods caused ongoing concern. However, with variation of wastewater treatment processes, the "Energy Consumption" $(129 ; 1.6 \%)$ played a crucial role to evaluate the fate of different kinds of methods (Batstone et al. 2015; McCarty et al. 2011), which possess a significant increment in its ranking from not available in 1991-1995 to 16th in 2011-2015. "Activated Sludge" $(136,1.7 \%)$ are continuously losing the core attention, moving down in rankings from 2nd in 1991-1995 to 19th in
Fig. 7 Network diagram of top 30 author keywords during period 1991 to 2015

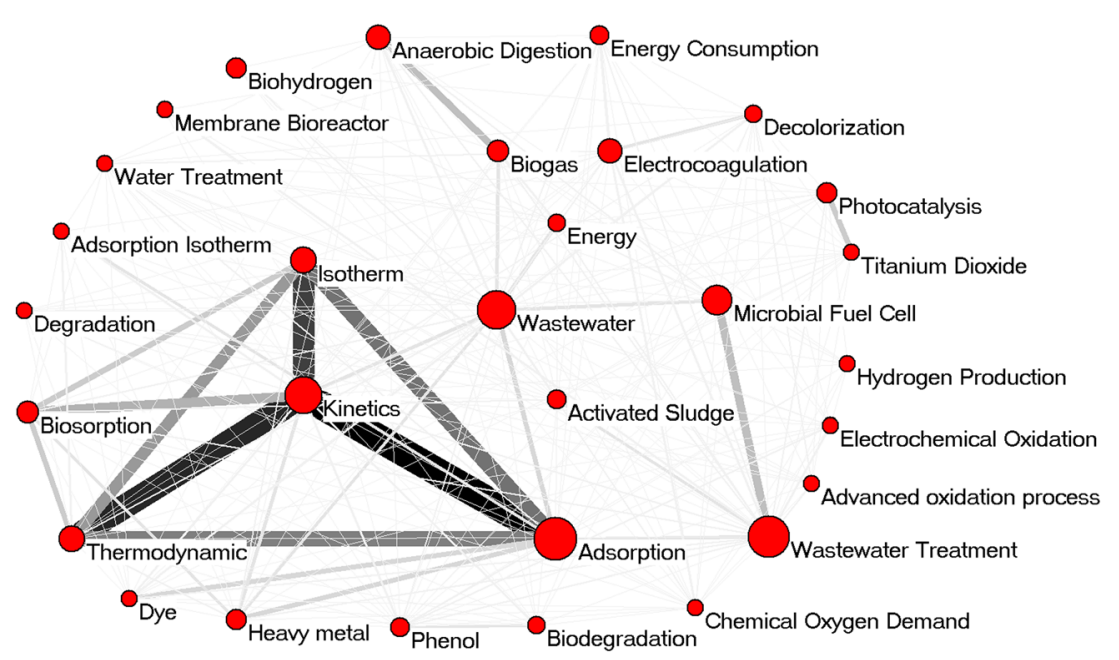


2011-2015, which should be attributed to its favorable performance during resource utilization (Fytili and Zabaniotou 2008).

\section{Hotspot and prospective tendency}

Analysis of research themes, hotspot and prospective tendency, could be undertook by way of exploring author keywords and titles of articles (Baskerville 1904). "KeyWords Plus" was automatic acquired by SCI-EXPANDED based on an algorithm, which derived keywords via either referred or cited titles of publications (Garfield 1990). Further, the information of abstracts was also used to study the tendency of research theme (Zhang et al. 2010; Zyoud et al. 2017). A novel method called "word cluster analysis" (Mao et al. 2010), comprising author keywords, "KeyWords Plus," title, and abstracts, has been broadly used to explore the research focus from published literatures (Li et al. 2011; Tan et al. 2014).

Research tendencies for wastewater-energy nexus study were derived and divided into four categories of (i) wastewater kinds (Fig. 8a: "municipal wastewater," "industrial wastewater," and "domestic wastewater"; Fig. 8b: "dyeing wastewater," "phenol wastewater," "textile wastewater," "wastewater containing heavy metals," and "pharmaceutical wastewater"), (ii) treatment processes (Fig. 8c: "adsorption," "biosorption," "anaerobic digestion," and "reverse osmosis"; Fig. 8d: "microbial fuel cell," "electrocoagulation," "photocatalysis," and "electrochemical oxidation"), (iii) bioenergy (Fig. 8e: "hydrogen," "methane," "biogas," "biohydrogen," and "ethanol"; Fig. 8f: "biomass," "algae," "biofuel," "microalgae," and "biodiesel"), and (iv) energy evaluation (Fig. 8g: "energy consumption," "energy recovery," "energy efficiency," "energy saving," "electricity generation," and "energy balance"; Fig. 8h: "sustainability," "life cycle assessment (LCA)," "environmental impact," "renewable energy," "greenhouse gas," and "solar energy"). Figure 8 shows the growth tendency of hotpot articles from 1991 to 2015.

As an inevitable corollary consequence of the exponential increase in urbanization and industrialization throughout the nineteenth century, the prevalence of unhealthy environments rapidly increased, and widespread epidemic diseases became increasingly commonplace (van Loosdrecht and Brdjanovic 2014). The increase in disease epidemics can be attributed, at least in part, to indiscriminately discharged wastewater. The wastewater is characteristically complicated in its components, comprising heavy metals, refractory organics, and pathogens (Fu and Wang 2011). Therefore, it is imperative to present the dynamic variation of the discharged effluent in space-time scale. Figure $8 \mathrm{a}$ shows that municipal wastewater and industrial wastewater-related research increased significantly in the last decade. Presently, municipal wastewater treatment plants are becoming increasingly called upon to meet the stringent emission standards required to satisfy the greater demand for high security in water quality (Zheng et al. 2015b). The increasing amount and types of industrial wastewater comprises refractory organics and inorganics, with the complicated components, high toxicity, and low biodegradability (Zheng et al. 2015c, Zyoud et al. 2016). In a sense, due to the broad and serious water pollution and threaten to human health and safety, the proper disposal of industrial wastewater is more important in comparison to municipal wastewater (Yang et al. 2016; Zheng et al. 2015a, e, 2016b). Interestingly, the upward tendency of domestic wastewater downturn since 2013 should be attributed to the mature treatment system and improvement of public environmental awareness. In the current study, the industrial wastewater mainly focused on dyeing wastewater, phenol wastewater, textile wastewater, wastewater containing heavy metals, and pharmaceutical wastewater (Fig. 8b). The dyeing wastewaterrelated research ranked the first since 2007, and distantly followed by the others. Driven by increasing demand, dyes, including natural dyes and synthetic dyes, achieved a rapid increase in production (Haddar et al. 2014; Yagub et al. 2014). Natural dyes, without any chemical processing, were defined as ecological, biodegradable, and low allergenic products, which gained an extensive interest under the increasing recognition of health (Ghouila et al. 2012). However, with the industrialization of food, pharmaceutical, and cosmetic fields, the amount of natural dyes cannot satisfy the expected demand by its low availability and the high processing cost of natural coloring substances (Haddar et al. 2014). Therefore, an abundant, cheap, and renewable source is wanted; considerable attention has been drawn to raw materials produced from farming, forestry, and non-food crops due to their characteristics in natural coloring substances including (Prusty et al. 2010). The natural dyes ere also notably applied in textile industry (Shahid-ul-Islam et al. 2013), that is why the relatively high interest in textile wastewater-related research. The phenol compounds in phenolic wastewater are toxic, carcinogenic, mutagenic, and teratogenic (Autenrieth et al. 1991), which have attracted people's attention due to its widespread occurrence and bio-recalcitrant nature in soils, sediments, and water bodies (Van Aken et al. 2015). Meanwhile, it is vital to treat phenolic wastewater at low-cost levels. A low-cost material, such as fungal biomass, sludge materials, and chitosan, is applied for the treatment of phenolic compounds from the effluent, which was cheap, locally available, and effective material with promising potential for commercial application in the future by comparison to commercial activated carbon (Ahmaruzzaman 2008). Distinguished from phenolic wastewater, the wastewater containing heavy metals presents real threats to human beings by reason of its bioaccumulation through food chain (Khan et al. 2008). The heavy metals including copper $(\mathrm{Cu})$, chromium $(\mathrm{Cr})$, cadmium $(\mathrm{Cd})$, zinc $(\mathrm{Zn})$, nickel $(\mathrm{Ni})$, silver $(\mathrm{Ag})$, mercury $(\mathrm{Hg})$, and lead $(\mathrm{Pb})$ of were respectively revealed 468, 414, 295, 259, 208, 89, 81, 
(a)

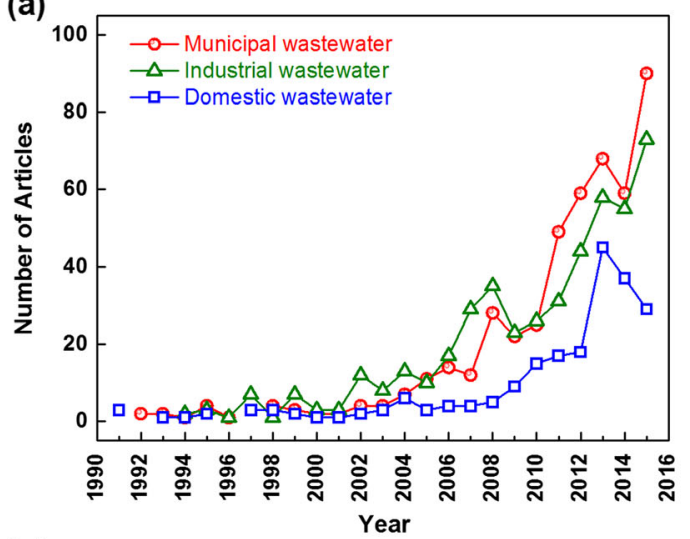

(c)

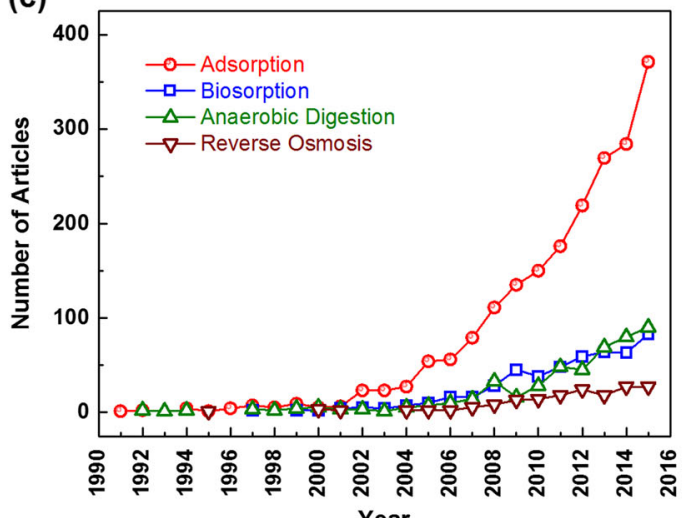

(e)

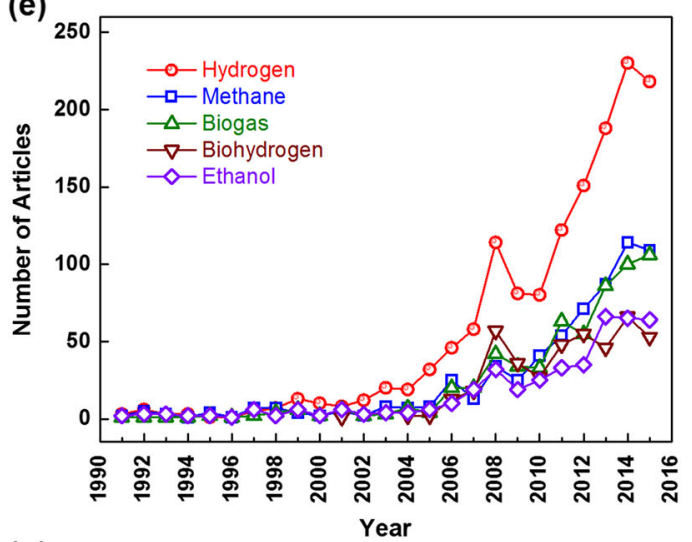

(g)

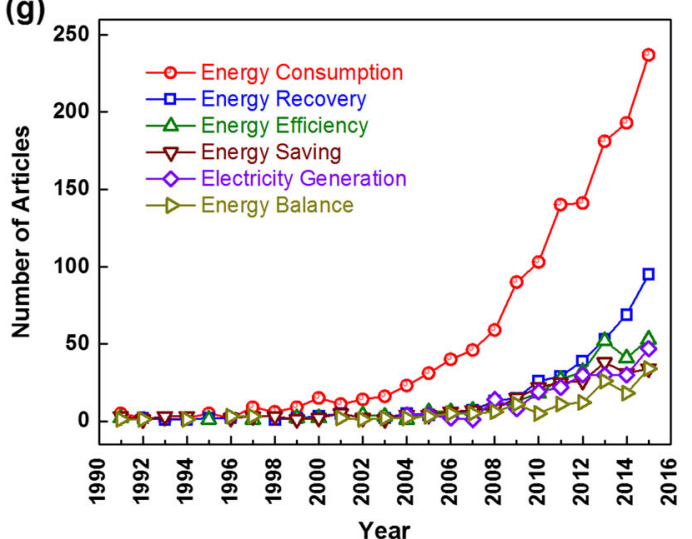

(b)

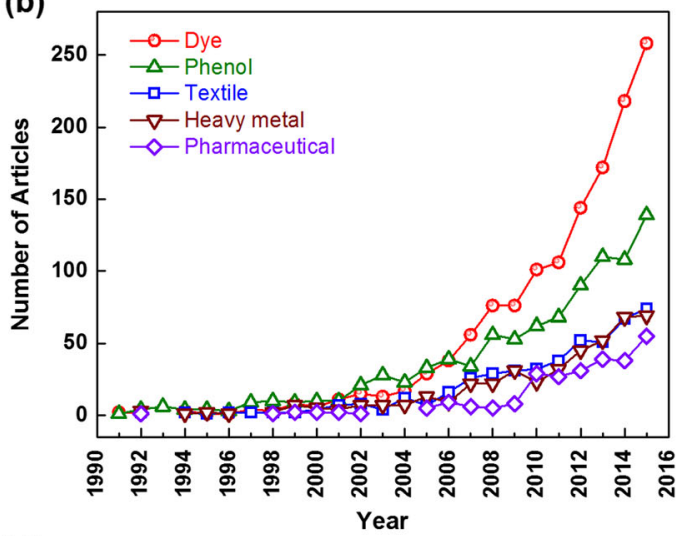

(d)
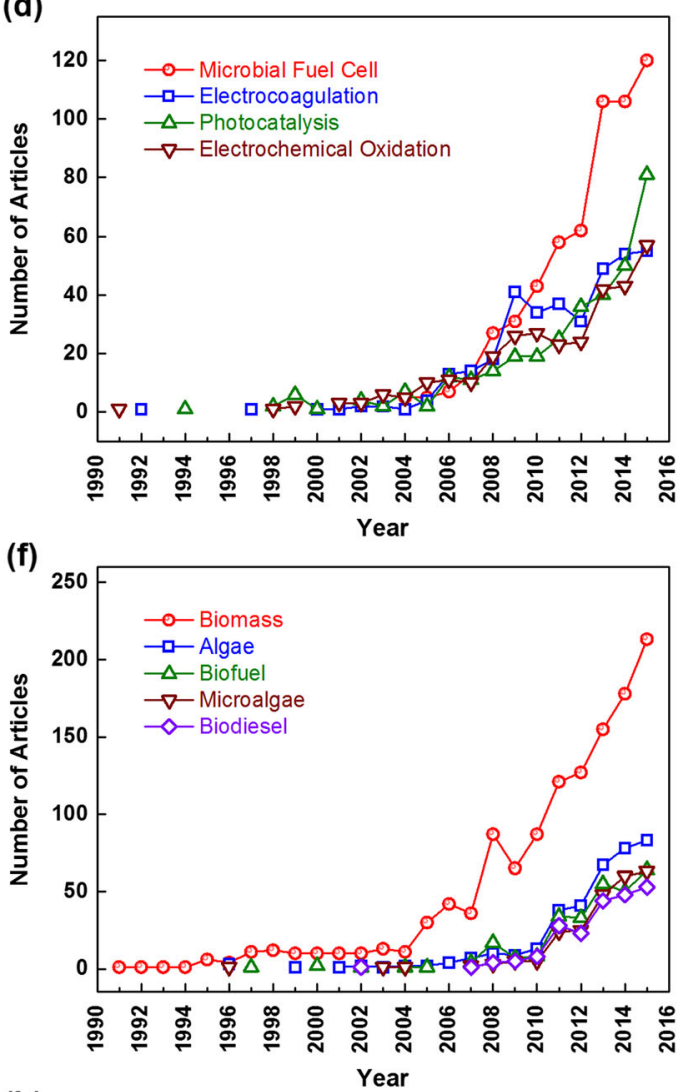

(h)

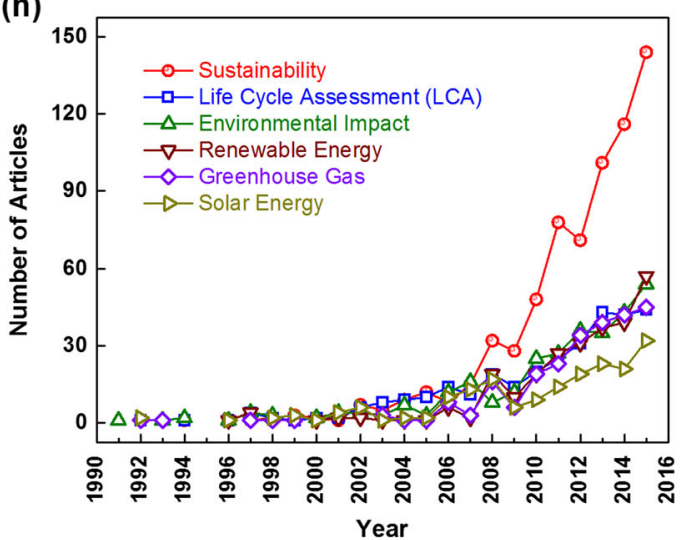

Fig. 8 Growth tendency of hotpot articles from 1991 to 2015 
and 50 times in the published literatures. Therefore, with the exception of the recovery parts, the other wastewater containing heavy metals should adopt harmless treatment to avoid their transfer-transformation behavior. In addition, the pharmaceutical wastewater including antibiotic wastewater, synthetic drug production wastewater, and Chinese traditional pharmacy wastewater also provoked a common concern on its treatment followed with flourishing pharmaceutical industry, which was characteristically complicated in its high amount of organic content, high toxicity, high salt content, deep color and low biodegradability, as well as the intermittently discharged properties. The effectively comprehensive treatment method also should be encouraged to avoid human beings being exposed to pharmaceutically active compounds. It is terrible that the compounds were detected at trace-levels in ground and drinking water of some countries (Heberer 2002).

With the threat of the emerging issues in regard to variations of types and amounts of wastewater, an advanced, effective, and sanitary technique should be undertaken in response to the tough future of human beings (van Loosdrecht and Brdjanovic 2014). Figure 8c, d show that adsorption, biosorption, anaerobic digestion, reverse osmosis, MFC, electrocoagulation, photocatalysis, and electrochemical oxidation are widely used techniques of wastewater-energy nexus study. Adsorption, one of time-honored wastewater treatment process, has kept a dominate place throughout the research period. Presently, the process with alternatively low-cost adsorbents could specifically target to treatment of wastewater including dye, heavy metal, and phenol (Barakat 2011; Hamdaoui and Naffrechoux 2007; Yagub et al. 2014). Further, biosorption defined as a novel bioremediation technique possess great potential on wastewater treatment (Aksu 2005), especially for the heavy metals containing wastewater treatment (shown in Fig. 7). Further, biosorbents, which are cheap, feasible, and environmental-friendly, are the essential question to support biosorption technique (Ali and Gupta 2006). A variety of novel biomaterials are focused on bacteria, fungus, microalgae, and agriculture residue (Konur 2011; Vijayaraghavan and Yun 2008). For example, the most frequently author keywords of "chitosan" moved up from a ranking of not available in 1991-1995 to 74th (47; 0.6\%) in 20112015. Anaerobic digestion, as one of potentially positive energy treatment process, has been applied to recycle and store methane, hydrogen, and electricity from the chemical energy of organic carbon in wastewater (Shoener et al. 2014). Codigestion with other agricultural waste and activated sludge is an attractive pathway to assist the adaptation of microorganisms to inhibitory materials and to eliminate the toxicants before anaerobic digestion, which is beneficial to improve treatment efficiency (Chen et al. 2008). Reverse osmosis apparently increased because of its driving separation performance and water productivity during the treatment and reuse of industrial wastewater (Greenlee et al. 2009). Presently, under stringent water standards, the reverse osmosis technique is paying great attention on the materials development of reverse osmosis membrane, which can serve as a kind of multi-functional membrane materials that provide high permeability, higher ions and organics pollutants rejection, and operation stability (Lee et al. 2011). It is foreseeable that the emergence of nano-technique could revolutionarily promote the development of membrane materials science; however, the challenges of practical application still existed for the desalination performance of reverse osmosis in the future (Shenvi et al. 2015). MFC is a novel sustainable process for both wastewater treatment and bioenergy production (Oh and Logan 2005; Rabaey and Verstraete 2005), which occupied an important position when firstly revealed in 2004 during wastewater-energy nexus-related research (Fig. 8d). Presently, variation of attention was focused on the configuration, substrates, electrode materials, separators, and microbiology of MFC, the large-scale and realworld application of this technique was barely involved ( $\mathrm{Li}$ et al. 2014). It is hard to realize the ultimate goal of MFC, which could economically confront the uncertain challenge of wastewater treatment. Electrocoagulation is an effective technique to eliminate nutrients and organics from different kinds of water and wastewaters, especially for industrial wastewater (Tian et al. 2017), which has fluctuated since 2009 and has an apparent decelerated growth tendency in recent years (Fig. 8d). This could be because of intensive-energy requirements and the controversial sustainable concept of electrocoagulation during wastewater-energy nexus research field. Figure $8 \mathrm{~d}$ shows that the photocatalysis research first appeared in 1994, fluctuated in 1998-2005, and then significantly increased in last decade, which revealed the potential value of photocatalysis technology. Underneath wastewater-energy nexus-related research, solar-driven photocatalysis process could be applied for desalination, detoxification, and disinfection (Blanco et al. 2009), which imply the solar-based technique was coordinated to sustainable strategy to resolve energy and wastewater problems. Electrochemical oxidation is deemed to be a suitable method to mineralize the refractory organic compounds through direct and indirect oxidation (Martinez-Huitle and Ferro 2006; Zheng et al. 2016c).

Though a lot of effective and novel techniques displayed in Fig. 8c, d could absolutely satisfy the requirement of variation of wastewater described in Fig. 8a, b, the environmentalfriendly technique with nutrient and energy resource recovery is the tomorrow in the face of fossil fuel depletion, globalscale energy security, and climate change (Li and Yu 2011). In order to deal with those problems, renewable energy, one of the most efficient techniques, deserves more attention to achieve sustainable development (Goldemberg 2007). Figure 8e shows that hydrogen ranked 1st and remarkably increased during last 10 years. Hydrogen is characteristically promising in its higher transfer efficacy, recycle capacity, and 
non-polluted character, which was deemed to be the future of global fuel (Das and Veziroğlu 2001). Biohydrogen generation is observed to be a lower energy consumption technique in comparison to thermo- and electro-chemical processes. That is why the production of biohydrogen remains in good momentum throughout the last decade (shown in Fig. 8e). Further, the renewable energy sources like biomass was always used for the production of the cleanest energy carrier for the use of mankind during biohydrogen technique (Das and Veziroglu 2008), which could explain why the increasing tendency of biomass was strongly positively correlated with that of hydrogen (shown in Fig. 8f). It is found that the core research of biomass is central in biomass resource expansion, biomass conversion techniques, and eco-environmental utilization of the biomass energy (Du et al. 2014). Figure 8e also showed that the related research of methane and biogas possess a positively significant interaction with the slope $(\mathrm{k})$ and $R^{2}$ of 0.94 and 0.9704 , respectively. This result reveal that the methane is usually associated with biogas during wastewaterenergy nexus-related research, which also could explain the words of biomethane abbreviated from methane-rich biogas. Further, the research of microalgae and algae have gained enormous progress followed with that of biogas (shown in Fig. 8f), which may be attributable to their characters to be a potential substrates during biogas production (Dębowski et al. 2013). Microalgae are also widely available as raw materials for biodiesel production (shown in Fig. 8f), which could effectively utilized the nitrogen nutrient, phosphorus nutrient, and toxic metals from wastewater to eliminate the overgrowth of harmful phytoplankton (Cai et al. 2013). However, pilot and large-scale algae cultivation are still a challenge in respect of various issues including contaminated pollutes, complex wastewater components, and uncontrolled biomass production (Nigam and Singh 2011). The selection and identification of algae species and their cultivating parameters optimization are vital in response to eutrophication of water receiving areas. Therefore, biodiesel, one kind of promising biofuel causing less air pollution, should naturally gain increasing support (Chen et al. 2015; Mao et al. 2015b; Xu and Boeing 2013). Compared with other forms of renewable bioenergy, bioethanol production from wastewater and biomass is a relatively mature industry, which has been universally applied in developed and developing countries (Balat et al. 2008; Goldemberg 2007; Koizumi 2013).

To realize the sustainable development goal during wastewater-energy nexus field, we cannot just rely on the recovery of renewable bioenergy but also for the corresponding evaluation indicator, method, and policy. That is to say, indulging in the illusion of prosperity of renewable bioenergy is certainly undesirable; positive bioenergy evaluation and rational government guidance is the proper pathway in prompting the progress of net wastewater-energy nexus-related research. Figure $8 \mathrm{~g}$ shows that energy consumption (steadily ranked 1st in the last two decades) has increasingly drawn great concern during whole research period, which distantly preceded the other evaluation indicators. The results imply that energy consumption is a lifeline of various techniques and bioenergy application; therefore, lower or negative energy consumption of wastewater treatment is ultimate mission for achieving sustainable development goals (Hering et al. 2016). As shown in Fig. 8g, h, energy recovery (Smith et al. 2014) and sustainability (Singh et al. 2012) of whole processes of wastewater treatment are the most important indicators to decide whether a technique or bioenergy could draw an indelible mark in history. Obviously, energy efficiency, energy saving, electricity generation, and energy balance are also attracting peoples' attention, which could comprehensively evaluate and identify suitable techniques in the renewable energy utilization, net-energy wastewater treatment, bioenergy resource recovery, and application. Further, energy efficacy was considered as the cost-saving selection in figuring greenhouse gas emissions (Du et al. 2015; Qiu 2014). LCA, first derived by Guinee in 1992 (Guinee 2002), is defined as the decision-maker technique to weight the societal, economic, and environmental implications. LCA has been widely applied in other environmental issues, such as energy recovery strategies of navigating wastewater (Smith et al. 2014), green building (Zuo et al. 2017), and low carbon (Wang et al. 2017). Further, LCA is always applied to appraise energy balance and internal environmental impact of all processes of techniques during wastewater treatment and bioenergy resource utilization, which is a beneficially supplementary assessment for the advanced techniques when they call forth economic interest and scientific behaviors (Lardon et al. 2009). Based on the evaluation method, it is found that renewable energy was popular and well-behaved during wastewater-energy nexus-related research. Renewable energy, first appeared in 1996, has an apparent incremental increase during last decade, which also implied this kind of energy was highly emphasis. Renewable energy including biomass (Chen and Ho 2015), solar (Lewis and Nocera 2006; Liping 2011), wind (Barton and Infield 2006; Gao et al. 2016; Lu et al. 2016), hydropower (Demirbas 2005; Jiang et al. 2016), geothermal (Ellabban et al. 2014; Mueller et al. 2015), and marine energies (Lam and Bhushan Roy 2014) was defined as an important, domestic, and clean or endless energy sources, which have occupied $14 \%$ of worldwide energy needs (Demirbas 2005). Biomass-based energy and solar energy are two of the most important renewable energies in the current study. Biomass-based bioenergy, which could be derived during the treatment process of wastewater, acts as an important role to realize net wastewater-energy technique system by achieving resource and energy recovery. Solar energy, on the other hand, which is clean and green forms of energy source, is promising to be applied for whole stage of wastewater treatment. Presently, solar-driven wastewater treatment process 
has performed well. For example, Wang's research team reported that a solely solar-driven electrochemical process was successfully applied for organic wastewater treatment, which has also been proved to be a green, efficient, safe, and sustainable process (Nie et al. 2016; Wang et al. 2012, 2013). However, innovation techniques on PV modules' efficiency, enhanced lifetime, less multi-silicon mass per module, and proper recovery should be focused and developed to reduce environmental impact in response to the generated greenhouse gas and e-garbage waste during solar industry (Aman et al. 2015).

\section{Novel wastewater-energy nexus concept}

In the past, wastewater treatment, regarded as an energyintensive process, was always focusing on the removal of organic carbon and other nutrient sources to comply with effluent discharge standards. With the passage of time, the concept of "wastewater is a valuable resource of bio-energy and nutrients" is gradually materializing, driven by sustainable development goals. Wastewater is an appealing pathway through which to recycle internal energies and bio-chemical from wastewater with a proper bioconversion process ( $\mathrm{Li}$ and Yu 2011; Mo and Zhang 2013). Presently, the development of emerging sustainable processes and novel renewable energy applications is a research hotspot, which was applied in response to the desired requirement for a net wastewater-energy nexus system. A similar concept was gradually applied in other environmental fields, such as, water-energy nexus ( $\mathrm{Gu}$ et al. 2016; Hamiche et al. 2016), municipal solid waste strategy (Scarlat et al. 2015), and food waste management (Ma et al. 2017). Obviously, the mutual dependency and tradeoffs between wastewater and energy are increasingly attracting more and more attention to realize a net wastewater-energy nexus system.

In our view, the net wastewater-energy nexus system appears promising to be achieved if the development of environmentally sustainable techniques and policies are thoroughly carried out. However, continuing efforts still need to be committed to making the energy consumption of wastewater treatment process possible to be an energy-positive model. Emerging wastewater treatment techniques should adopt a more holistic pathway, where renewable energy usage is increased from a little to more, energy consumption from negative to positive, and resource recovery from nothing to maximum. The future wastewater treatment operation should like this description "whole wastewater treatment techniques are driven by renewable energies, such as, solar, wind, hydropower, geothermal or their synergetic pattern; whole organic carbon, nutrients, and other resource are solely and jointly separated from the wastewater with a minimal economic cost under a regulatory platform; valuable energy resources such as biogas, biohydrogen, biomass, and others, are recycled to be utilized in the process of running the facility, or ultimately grid-connected for other utilizations." The sustainable wastewater-energy nexus makes realistic sense, especially in response to fossil fuel depletion, worldwide energy security, and increasingly severe climate change. In brief, the following three perspectives should be focused and taken in practice to make the vision come true: (i) enhanced application of renewable energy for wastewater treatment; (ii) cost-saving technique for proper and controlled wastewater treatment and reclamation; (iii) maximally explored potential energy and resource recovery from wastewater and its by-products.

\section{Conclusions}

This bibliometric study, proceeding on the basis of 9626 wastewater-energy nexus-related articles from SCIEXPANDED, historically retrospect the current tendency and hotspots of wastewater-energy nexus research, which revealed that the prospective hotspots focused on the development of emerging sustainable processes and novel renewable energy applications, in response to the desire for a net wastewater-energy nexus system. Based on various wastewater types of municipal wastewater, domestic wastewater, and industrial wastewater, the emerging energy and sources of recovery treatment processes, such as Anammox, AD, and MFC, captured peoples' attention due to its great potential for bioenergy (biogas, biohydrogen, methane, biomass, biofuel, and biodiesel) production. Meanwhile, based on energy consumption, energy efficiency, and energy recovery, evaluation methods in respect of sustainability, LCA, and environmental impact, were applied to assess whether the novel wastewater process was environmentally friendly, with renewable energy utilized, energy savings, and energy recovering. The new concept of "broaden income source, economize on expenditures and exploit inner potential" should be infused and cultivated to realize the environmentally sustainable development for wastewater-energy nexus. Holistically, it boils down to the following propositions: (i) continuously broaden the application of renewable energy for wastewater treatment; (ii) significantly economize the cost for rational wastewater treatment and reclamation; (iii) efficiently exploit potential energy and resource recovery from wastewater. In brief, the future of the net wastewater-energy nexus is worth waiting for.

Acknowledgements The authors would like to thank Mr. Nicholas Smale, who work hard to improve the English language in our manuscript.

Funding information This work was supported by the Major Projects of Science and Technology of Inner Mongolia Autonomous Regions since 2013 and the Major Science and Technology Program for Water Pollution Control and Treatment (grant numbers: 2014ZX07201-011-005-002). 


\section{References}

Ahmaruzzaman M (2008) Adsorption of phenolic compounds on lowcost adsorbents: a review. Adv Colloid Interfac 143(1-2):48-67. https://doi.org/10.1016/j.cis.2008.07.002

Aksu Z (2005) Application of biosorption for the removal of organic pollutants: a review. Process Biochem 40(3-4):997-1026. https:// doi.org/10.1016/j.procbio.2004.04.008

Ali I, Gupta VK (2006) Advances in water treatment by adsorption technology. Nat Protoc 1(6):2661-2667. https://doi.org/10.1038/nprot. 2006.370

Aman MM, Solangi KH, Hossain MS, Badarudin A, Jasmon GB, Mokhlis H, Bakar AHA, Kazi SN (2015) A review of safety, health and environmental (SHE) issues of solar energy system. Renew Sust Energ Rev 41:1190-1204. https://doi.org/10.1016/j.rser.2014.08. 086

Andrews N, Willis J, Muller C (2016) Assessment of technology advancements for future energy reduction. IWA Publishing, Alliance House 12, Caxton Street, London

Autenrieth RL, Bonner JS, Akgerman A, Okaygun M, McCreary EM (1991) Biodegradation of phenolic wastes. J Hazard Mater 28(1-2):29-53. https://doi.org/10.1016/0304-3894(91) 87004-L

Balat M, Balat H, Öz C (2008) Progress in bioethanol processing. Prog Energ Combust 34(5):551-573. https://doi.org/10.1016/j.pecs. 2007.11.001

Ball M, Wietschel M (2009) The future of hydrogen-opportunities and challenges. Int J Hydrogen Energ 34(2):615-627. https://doi.org/10. 1016/j.ijhydene.2008.11.014

Barakat MA (2011) New trends in removing heavy metals from industrial wastewater. Arab J Chem 4(4):361-377. https://doi.org/10.1016/j. arabjc.2010.07.019

Barton JP, Infield DG (2006) A probabilistic method for calculating the usefulness of a store with finite energy capacity for smoothing electricity generation from wind and solar power. J Power Sources 162(2):943-948. https://doi.org/10.1016/j. jpowsour.2005.07.006

Baskerville C (1904) The titles of papers. Science (New York, NY) 19(487):702-703. https://doi.org/10.1126/science.19.487.702

Batstone DJ, Virdis B (2014) The role of anaerobic digestion in the emerging energy economy. Curr Opin Biotech 27:142-149. https://doi.org/10.1016/j.copbio.2014.01.013

Batstone DJ, Hülsen T, Mehta CM, Keller J (2015) Platforms for energy and nutrient recovery from domestic wastewater: a review. Chemosphere 140:2-11. https://doi.org/10.1016/j.chemosphere. 2014.10.021

Bell M, Pavitt K (1997) Technological accumulation and industrial growth: contrasts between developed and developing countries. Cambridge University Press, Cambridge, pp 83-137

Blanco J, Malato S, Fernández-Ibañez P, Alarcón D, Gernjak W, Maldonado MI (2009) Review of feasible solar energy applications to water processes. Renew Sust Energ Rev 13(6-7):1437-1445. https://doi.org/10.1016/j.rser.2008.08.016

Cai T, Park SY, Li Y (2013) Nutrient recovery from wastewater streams by microalgae: status and prospects. Renew Sust Energ Rev 19:360 369. https://doi.org/10.1016/j.rser.2012.11.030

Chen G (2004) Electrochemical technologies in wastewater treatment. Sep Purif Technol 38(1):11-41. https://doi.org/10.1016/j.seppur. 2003.10.006

Chen H, Ho Y (2015) Highly cited articles in biomass research: a bibliometric analysis. Renew Sust Energ Rev 49:12-20. https:// doi.org/10.1016/j.rser.2015.04.060

Chen S, Yan G (1987) Development and application of an energy utilization system for organic wastewater. Water Sci Technol 19(12): $377-380$
Chen Y, Cheng JJ, Creamer KS (2008) Inhibition of anaerobic digestion process: a review. Bioresour Technol 99(10):4044 4064. https://doi. org/10.1016/j.biortech.2007.01.057

Chen H, Qiu T, Rong J, He C, Wang Q (2015) Microalgal biofuel revisited: an informatics-based analysis of developments to date and future prospects. Appl Energ 155:585-598. https://doi.org/10. 1016/j.apenergy.2015.06.055

Chiu WT, Huang JS, Ho YS (2004) Bibliometric analysis of severe acute respiratory syndrome-related research in the beginning stage. Scientometrics 61(1):69-77. https://doi.org/10.1023/B:SCIE. 0000037363.49623 .28

Cho K, Qu Y, Kwon D, Zhang H, Cid CA, Aryanfar A, Hoffmann MR (2014) Effects of anodic potential and chloride ion on overall reactivity in electrochemical reactors designed for solar-powered wastewater treatment. Environ Sci Technol 48(4):2377-2384. https://doi. org/10.1021/es404137u

Chong MN, Jin B, Chow CWK, Saint C (2010) Recent developments in photocatalytic water treatment technology: a review. Water Res 44(10):2997-3027. https://doi.org/10.1016/j.watres.2010.02.039

Chuang K, Wang M, Ho Y (2011) High-impact papers presented in the subject category of water resources in the essential science indicators database of the institute for scientific information. Scientometrics 87(3):551-562. https://doi.org/10.1007/s11192-011-0365-2

Das D, Veziroğlu TN (2001) Hydrogen production by biological processes: a survey of literature. Int J Hydrogen Energ 26(1):13-28. https:// doi.org/10.1016/S0360-3199(00)00058-6

Das D, Veziroglu TN (2008) Advances in biological hydrogen production processes. Int J Hydrogen Energ 33(21):6046-6057. https://doi.org/ 10.1016/j.ijhydene.2008.07.098

De Nooy W, Mrvar A, Batagelj V (2011) Exploratory social network analysis with Pajek, 27. Cambridge University Press, Cambridge. https://doi.org/10.1017/CBO9780511996368

Dębowski M, Zieliński M, Grala A, Dudek M (2013) Algae biomass as an alternative substrate in biogas production technologies - review. Renew Sust Energ Rev 27:596-604. https://doi.org/10.1016/j.rser. 2013.07.029

Demirbas A (2005) Potential applications of renewable energy sources, biomass combustion problems in boiler power systems and combustion related environmental issues. Prog Energ Combust 31(2):171192. https://doi.org/10.1016/j.pecs.2005.02.002

Du Z, Li H, Gu T (2007) A state of the art review on microbial fuel cells: a promising technology for wastewater treatment and bioenergy. Biotechnol Adv 25(5):464-482. https://doi.org/10.1016/j. biotechadv.2007.05.004

Du H, Li N, Brown MA, Peng Y, Shuai Y (2014) A bibliographic analysis of recent solar energy literatures: the expansion and evolution of a research field. Renew Energ 66:696-706. https://doi.org/10.1016/j. renene.2014.01.018

Du H, Li B, Brown MA, Mao G, Rameezdeen R, Chen H (2015) Expanding and shifting trends in carbon market research: a quantitative bibliometric study. J Clean Prod 103:104-111. https://doi.org/ 10.1016/j.jclepro.2014.05.094

Ellabban O, Abu-Rub H, Blaabjerg F (2014) Renewable energy resources: current status, future prospects and their enabling technology. Renew Sust Energ Rev 39:748-764. https://doi.org/10.1016/j. rser.2014.07.113

Finardi U (2015) Scientific collaboration between BRICS countries. Scientometrics 102(2):1139-1166. https://doi.org/10.1007/s11192014-1490-5

Foo KY, Hameed BH (2010) Insights into the modeling of adsorption isotherm systems. Chem Eng J 156(1):2-10. https://doi.org/10. 1016/j.cej.2009.09.013

Fu H, Ho Y (2016) Highly cited Antarctic articles using Science Citation Index Expanded: a bibliometric analysis. Scientometrics 109(1): 337-357. https://doi.org/10.1007/s11192-016-1992-4 
Fu F, Wang Q (2011) Removal of heavy metal ions from wastewaters: a review. J Environ Manag 92(3):407-418. https://doi.org/10.1016/j. jenvman.2010.11.011

Fu H, Wang M, Ho Y (2012) The most frequently cited adsorption research articles in the Science Citation Index (Expanded). J Colloid Interf Sci 379(1):148-156. https://doi.org/10.1016/j.jcis.2012.04. 051

Fu H, Wang M, Ho Y (2013) Mapping of drinking water research: a bibliometric analysis of research output during 1992-2011. Sci Total Environ 443:757-765. https://doi.org/10.1016/j.scitotenv. 2012.11.061

Fu H, Long X, Ho Y (2014) China's research in chemical engineering journals in Science Citation Index Expanded: a bibliometric analysis. Scientometrics 98(1):119-136. https://doi.org/10.1007/s11192013-1047-z

Fytili D, Zabaniotou A (2008) Utilization of sewage sludge in EU application of old and new methods - a review. Renew Sust Energ Rev 12(1):116-140. https://doi.org/10.1016/j.rser.2006.05.014

Gao W, Guo H (2014) Nitrogen research at watershed scale: a bibliometric analysis during 1959-2011. Scientometrics 99(3):737753. https://doi.org/10.1007/s11192-014-1240-8

Gao W, Chen Y, Liu Y, Guo H (2015) Scientometric analysis of phosphorus research in eutrophic lakes. Scientometrics 102(3):19511964. https://doi.org/10.1007/s11192-014-1500-7

Gao C, Sun M, Geng Y, Wu R, Chen W (2016) A bibliometric analysis based review on wind power price. Appl Energ 182:602-612. https://doi.org/10.1016/j.apenergy.2016.08.144

Garfield E (1990) Key-Words-Plus takes you beyond title words. 2. Expanded journal coverage for current-contents-on-diskette includes social and behavioral-sciences. Current Contents 33:5-9

Ghouila H, Meksi N, Haddar W, Mhenni MF, Jannet HB (2012) Extraction, identification and dyeing studies of Isosalipurposide, a natural chalcone dye from Acacia cyanophylla flowers on wool. Ind Crop Prod 35(1):31-36. https://doi.org/10.1016/j.indcrop.2011.05. 026

Goldemberg J (2007) Ethanol for a sustainable energy future. Science 315(5813):808-810. https://doi.org/10.1126/science.1137013

Greenlee LF, Lawler DF, Freeman BD, Marrot B, Moulin P (2009) Reverse osmosis desalination: water sources, technology, and today's challenges. Water Res 43(9):2317-2348. https://doi.org/10. 1016/j.watres.2009.03.010

Gu Y, Dong Y, Wang H, Keller A, Xu J, Chiramba T, Li F (2016) Quantification of the water, energy and carbon footprints of wastewater treatment plants in China considering a water-energy nexus perspective. Ecol Indic 60:402-409. https://doi.org/10.1016/j. ecolind.2015.07.012

Guinee JB (2002) Handbook on life cycle assessment operational guide to the ISO standards. Int J Life Cycle Assess 7(5):311-313. https:// doi.org/10.1007/BF02978897

Haddar W, Baaka N, Meksi N, Elksibi I, Mhenni MF (2014) Optimization of an ecofriendly dyeing process using the wastewater of the olive oil industry as natural dyes for acrylic fibres. J Clean Prod 66:546-554. https://doi.org/10.1016/j.jclepro.2013.11.017

Hamdaoui O, Naffrechoux E (2007) Modeling of adsorption isotherms of phenol and chlorophenols onto granular activated carbon: part I. Two-parameter models and equations allowing determination of thermodynamic parameters. J Hazard Mater 147(1):381-394. https://doi.org/10.1016/j.jhazmat.2007.01.021

Hamiche AM, Stambouli AB, Flazi S (2016) A review of the waterenergy nexus. Renew Sust Energ Rev 65:319-331. https://doi.org/ 10.1016/j.rser.2016.07.020

Heberer T (2002) Occurrence, fate, and removal of pharmaceutical residues in the aquatic environment: a review of recent research data. Toxicol Lett 131(1-2):5-17. https://doi.org/10.1016/S03784274(02)00041-3
Hering JG, Maag S, Schnoor JL (2016) A call for synthesis of water research to achieve the sustainable development goals by 2030 . Environ Sci Technol 50(12):6122-6123. https://doi.org/10.1021/ acs.est.6b02598

Ho Y, Satoh H, Lin S (2010) Japanese lung cancer research trends and performance in Science Citation Index. Internal Med 49(20):2219 2228. https://doi.org/10.2169/internalmedicine.49.3687

Hobus I, Hegemann W (2003) Renewable energy for the aeration of wastewater ponds. Water Sci Technol 48(2):365-372

Hou Q, Mao G, Zhao L, Du H, Zuo J (2015) Mapping the scientific research on life cycle assessment: a bibliometric analysis. Int $\mathrm{J}$ Life Cycle Assess 20(4):541-555. https://doi.org/10.1007/s11367015-0846-2

Hülsen T, Batstone DJ, Keller J (2014) Phototrophic bacteria for nutrient recovery from domestic wastewater. Water Res 50:18-26. https:// doi.org/10.1016/j.watres.2013.10.051

Jiang H, Qiang M, Lin P (2016) A topic modeling based bibliometric exploration of hydropower research. Renew Sust Energ Rev 57: 226-237. https://doi.org/10.1016/j.rser.2015.12.194

Kannan N, Vakeesan D (2016) Solar energy for future world: a review. Renew Sust Energ Rev 62:1092-1105. https://doi.org/10.1016/j. rser.2016.05.022

Katz JSAH (1997) Desktop scientometrics. Scientometrics 38(1):141153. https://doi.org/10.1007/BF02461128

Khan S, Cao Q, Zheng YM, Huang YZ, Zhu YG (2008) Health risks of heavy metals in contaminated soils and food crops irrigated with wastewater in Beijing, China. Environ Pollut 152(3):686-692. https://doi.org/10.1016/j.envpol.2007.06.056

King DA (2004) The scientific impact of nations. Nature 430(6997):311316. https://doi.org/10.1038/430311a

Koizumi T (2013) Biofuel and food security in China and Japan. Renew Sust Energ Rev 21:102-109. https://doi.org/10.1016/j.rser.2012.12. 047

Konur O (2011) The scientometric evaluation of the research on the algae and bio-energy. Appl Energ 88(10):3532-3540. https://doi.org/10. 1016/j.apenergy.2010.12.059

Lam W, Bhushan Roy C (2014) Insights into the Ocean Health Index for marine renewable energy. Renew Sust Energ Rev 33:26-33. https:// doi.org/10.1016/j.rser.2014.01.078

Lardon L, Helias A, Sialve B, Steyer J, Bernard O (2009) Life-cycle assessment of biodiesel production from microalgae. Environ Sci Technol 43(17):6475-6481. https://doi.org/10.1021/es900705j

Le-Clech P, Chen V, Fane TAG (2006) Fouling in membrane bioreactors used in wastewater treatment. J Membrane Sci 284(1-2):17-53. https://doi.org/10.1016/j.memsci.2006.08.019

Lee KP, Arnot TC, Mattia D (2011) A review of reverse osmosis membrane materials for desalination - development to date and future potential. J Membrane Sci 370(1-2):1-22. https://doi.org/10.1016/ j.memsci.2010.12.036

Lewis NS, Nocera DG (2006) Powering the planet: chemical challenges in solar energy utilization. Proc Natl Acad Sci 103(43):15729 15735. https://doi.org/10.1073/pnas.0603395103

Li W, Yu H (2011) From wastewater to bioenergy and biochemicals via two-stage bioconversion processes: a future paradigm. Biotechnol Adv 29(6):972-982. https://doi.org/10.1016/j.biotechadv.2011.08. 012

Li W, Zhao Y (2015) Bibliometric analysis of global environmental assessment research in a 20-year period. Environ Impact Assess Rev 50:158-166. https://doi.org/10.1016/j.eiar.2014.09.012

Li XZ, Liu H, Cheng LF, Tong HJ (2003) Photocatalytic oxidation using a new catalyst $\mathrm{TiO}_{2}$ microsphere for water and wastewater treatment. Environ Sci Technol 37(17):3989-3994. https://doi.org/10. 1021/es0262941

Li J, Wang M, Ho Y (2011) Trends in research on global climate change: a Science Citation Index Expanded-based analysis. Glob Planet 
Chang 77(1-2):13-20. https://doi.org/10.1016/j.gloplacha.2011.02. 005

Li W, Yu H, He Z (2014) Towards sustainable wastewater treatment by using microbial fuel cells-centered technologies. Energy Environ Sci 7(3):911-924

Duan L (2011) Analysis of the relationship between international cooperation and scientific publications in energy R\&D in China. Appl Energ 88(12): 4229-4238. https://doi.org/10.1016/j.apenergy.2011. 02.045

Liu Y, Liu Y (2008) Biosorption isotherms, kinetics and thermodynamics. Sep Purif Technol 61(3):229-242. https://doi.org/10.1016/j.seppur. 2007.10.002

Liu H, Logan BE (2004) Electricity generation using an air-cathode single chamber microbial fuel cell in the presence and absence of a proton exchange membrane. Environ Sci Technol 38(14):4040 4046. https://doi.org/10.1021/es0499344

Liu Z, Guan D, Crawford-Brown D, Zhang Q, He K, Liu J (2013) Energy policy: a low-carbon road map for China. Nature 500(7461):143145. https://doi.org/10.1038/500143a

Liu Y, Yu H, Ng WJ, Stuckey DC (2015) Wastewater-energy nexus. Chemosphere 140:1. https://doi.org/10.1016/j.chemosphere.2015. 06.012

Lo K (2014) A critical review of China's rapidly developing renewable energy and energy efficiency policies. Renew Sust Energ Rev 29: 508-516. https://doi.org/10.1016/j.rser.2013.09.006

Logan BE, Regan JM (2006) Microbial fuel cells — challenges and applications. Environ Sci Technol 40(17):5172-5180. https://doi.org/10. 1021/es0627592

Lu X, McElroy MB, Peng W, Liu S, Nielsen CP, Wang H (2016) Challenges faced by China compared with the US in developing wind power. Nature Energy 1(6):16061. https://doi.org/10.1038/ nenergy.2016.61

Ma Y, Yin Y, Liu Y (2017) A holistic approach for food waste management towards zero-solid disposal and energy/resource recovery. Bioresour Technol 228:56-61. https://doi.org/10.1016/j.biortech. 2016.12.090

Malato S, Blanco J, Vidal A, Richter C (2002) Photocatalysis with solar energy at a pilot-plant scale: an overview. Appl Catal B Environ 37(1):1-15. https://doi.org/10.1016/S0926-3373(01)00315-0

Manju S, Sagar N (2017) Progressing towards the development of sustainable energy: a critical review on the current status, applications, developmental barriers and prospects of solar photovoltaic systems in India. Renew Sust Energ Rev 70:298-313. https://doi.org/10. 1016/j.rser.2016.11.226

Mao N, Wang M, Ho Y (2010) A bibliometric study of the trend in articles related to risk assessment published in science citation index. Hum Ecol Risk Assess 16(4):801-824. https://doi.org/10.1080/ 10807039.2010.501248

Mao G, Liu X, Du H, Zuo J, Wang L (2015a) Way forward for alternative energy research: a bibliometric analysis during 1994-2013. Renew Sust Energ Rev 48:276-286. https://doi.org/10.1016/j.rser.2015.03. 094

Mao G, Zou H, Chen G, Du H, Zuo J (2015b) Past, current and future of biomass energy research: a bibliometric analysis. Renew Sust Energ Rev 52:1823-1833. https://doi.org/10.1016/j.rser.2015.07.141

Martinez-Huitle CA, Ferro S (2006) Electrochemical oxidation of organic pollutants for the wastewater treatment: direct and indirect processes. Chem Soc Rev 35(12):1324-1340. https://doi.org/10.1039/ B517632H

McCarty PL, Bae J, Kim J (2011) Domestic wastewater treatment as a net energy producer - can this be achieved? Environ Sci Technol 45(17):7100-7106. https://doi.org/10.1021/es2014264

Mo W, Zhang Q (2013) Energy-nutrients-water nexus: integrated resource recovery in municipal wastewater treatment plants. J Environ Manag 127:255-267. https://doi.org/10.1016/j.jenvman. 2013.05.007
Mueller SC, Sandner PG, Welpe IM (2015) Monitoring innovation in electrochemical energy storage technologies: a patent-based approach. Appl Energ 137:537-544. https://doi.org/10.1016/j. apenergy.2014.06.082

Nature Index (2014) Chinese Academy of Sciences. Nature 516(7531): S56-S57. https://doi.org/10.1038/516S56a

Nie C, Shao N, Wang B, Yuan D, Sui X, Wu H (2016) Fully solar-driven thermo- and electrochemistry for advanced oxidation processes (STEP-AOPs) of 2-nitrophenol wastewater. Chemosphere 154: 604-612. https://doi.org/10.1016/j.chemosphere.2016.04.020

Nigam PS, Singh A (2011) Production of liquid biofuels from renewable resources. Prog Energ Combust 37(1):52-68. https://doi.org/10. 1016/j.pecs.2010.01.003

Niu B, Loáiciga HA, Wang Z, Zhan FB, Hong S (2014) Twenty years of global groundwater research: a Science Citation Index Expandedbased bibliometric survey (1993-2012). J Hydrol 519:966-975. https://doi.org/10.1016/j.jhydrol.2014.07.064

Oh S, Logan BE (2005) Hydrogen and electricity production from a food processing wastewater using fermentation and microbial fuel cell technologies. Water Res 39(19):4673-4682. https://doi.org/10. 1016/j.watres.2005.09.019

Parsons S (2005) Advanced oxidation processes for water and wastewater treatment. Water Intelligence Online 4

Persson O (1994) The intellectual base and research fronts of JASIS 1986-1990. J Am Soc Inf Sci 45(1):31-38. https://doi.org/10.1002/ (SICI)1097-4571(199401)45:1<31::AID-ASI4>3.0.CO;2-G

Persson O, Danell R, Schneider JW (2009) How to use Bibexcel for various types of bibliometric analysis. Celebrating Scholarly Communication Studies: A Festschrift for Olle Persson at his 60th Birthday: 9-24

Prieto-Rodriguez L, Miralles-Cuevas S, Oller I, Agüera A, Puma GL, Malato S (2012) Treatment of emerging contaminants in wastewater treatment plants (WWTP) effluents by solar photocatalysis using low $\mathrm{TiO} 2$ concentrations. J Hazard Mater 211-212:131-137. https://doi.org/10.1016/j.jhazmat.2011.09.008

Prusty AK, Das T, Nayak A, Das NB (2010) Colourimetric analysis and antimicrobial study of natural dyes and dyed silk. J Clean Prod 18(16-17):1750-1756. https://doi.org/10.1016/j.jclepro.2010.06. 020

Qiu Y (2014) Energy efficiency and rebound effects: an econometric analysis of energy demand in the commercial building sector. Environmental \& Resource Economics 59(2):295-335. https://doi. org/10.1007/s10640-013-9729-9

Qu X, Alvarez PJJ, Li Q (2013) Applications of nanotechnology in water and wastewater treatment. Water Res 47(12):3931-3946. https://doi. org/10.1016/j.watres.2012.09.058

Rabaey K, Verstraete W (2005) Microbial fuel cells: novel biotechnology for energy generation. Trends Biotechnol 23(6):291-298. https:// doi.org/10.1016/j.tibtech.2005.04.008

Salager-Meyer F (2008) Scientific publishing in developing countries: challenges for the future. J Engl Acad Purp 7(2):121-132. https:// doi.org/10.1016/j.jeap.2008.03.009

Scarlat N, Motola V, Dallemand JF, Monforti-Ferrario F, Mofor L (2015) Evaluation of energy potential of municipal solid waste from African urban areas. Renew Sust Energ Rev 50:1269-1286. https://doi.org/10.1016/j.rser.2015.05.067

Shahid-ul-Islam, Shahid M, Mohammad F (2013) Perspectives for natural product based agents derived from industrial plants in textile applications - a review. J Clean Prod 57:2-18. https://doi.org/10. 1016/j.jclepro.2013.06.004

Sharma S, Thomas VJ (2008) Inter-country R\&D efficiency analysis: an application of data envelopment analysis. Scientometrics 76(3): 483-501. https://doi.org/10.1007/s11192-007-1896-4

Shenvi SS, Isloor AM, Ismail AF (2015) A review on RO membrane technology: developments and challenges. Desalination 368:10 26. https://doi.org/10.1016/j.desal.2014.12.042 
Shoener BD, Bradley IM, Cusick RD, Guest JS (2014) Energy positive domestic wastewater treatment: the roles of anaerobic and phototrophic technologies. Environmental Science: Processes \& Impacts 16(6):1204-1222. https://doi.org/10. 1039/c3em00711a

Singh RK, Murty HR, Gupta SK, Dikshit AK (2012) An overview of sustainability assessment methodologies. Ecol Indic 15(1):281-299. https://doi.org/10.1016/j.ecolind.2011.01.007

Smith AL, Stadler LB, Cao L, Love NG, Raskin L, Skerlos SJ (2014) Navigating wastewater energy recovery strategies: a life cycle comparison of anaerobic membrane bioreactor and conventional treatment systems with anaerobic digestion. Environ Sci Technol 48(10): 5972-5981. https://doi.org/10.1021/es5006169

Sun J, Wang M, Ho Y (2012) A historical review and bibliometric analysis of research on estuary pollution. Mar Pollut Bull 64(1):13-21. https://doi.org/10.1016/j.marpolbul.2011.10.034

Sun M, Zhai L, Li W, Yu H (2016) Harvest and utilization of chemical energy in wastes by microbial fuel cells. Chem Soc Rev 45(10): 2847-2870. https://doi.org/10.1039/C5CS00903K

Tan J, Fu H, Ho Y (2014) A bibliometric analysis of research on proteomics in Science Citation Index Expanded. Scientometrics 98(2): 1473-1490. https://doi.org/10.1007/s11192-013-1125-2

Tian Y, He W, Zhu X, Yang W, Ren N, Logan BE (2017) An improved electrocoagulation reactor for rapid removal of phosphate from wastewater. ACS Sustain Chem Eng 5(1):67-71. https://doi.org/ 10.1021/acssuschemeng.6b01613

Van Aken P, Van den Broeck R, Degrève J, Dewil R (2015) The effect of ozonation on the toxicity and biodegradability of 2,4-dichlorophenol-containing wastewater. Chem Eng J 280:728-736. https://doi. org/10.1016/j.cej.2015.06.019

van Loosdrecht MCM, Brdjanovic D (2014) Anticipating the next century of wastewater treatment. Science 344(6191):1452-1453. https://doi.org/10.1126/science.1255183

Verstraete W, Van de Caveye P, Diamantis V (2009) Maximum use of resources present in domestic "used water". Bioresour Technol 100(23):5537-5545. https://doi.org/10.1016/j.biortech.2009.05.047

Vijayaraghavan K, Yun Y (2008) Bacterial biosorbents and biosorption. Biotechnol Adv 26(3):266-291. https://doi.org/10.1016/j. biotechadv.2008.02.002

Wang B, Wu H, Zhang G, Licht S (2012) STEP wastewater treatment: a solar thermal electrochemical process for pollutant oxidation. ChemSusChem 5(10):2000-2010. https://doi.org/10.1002/cssc. 201200305

Wang B, Hu Y, Wu H, Licht S (2013) Solar driven thermal electrochemical process (STEP) wastewater treatment with synergistic production of hydrogen. Ecs Electrochem Lett 2(9):H34-H36. https://doi. org/10.1149/2.008309eel

Wang X, McCarty PL, Liu J, Ren N, Lee D, Yu H, Qian Y, Qu J (2015) Probabilistic evaluation of integrating resource recovery into wastewater treatment to improve environmental sustainability. Proc Natl Acad Sci 112(5):1630-1635. https://doi.org/10.1073/pnas. 1410715112

Wang L, Zhao L, Mao G, Zuo J, Du H (2017) Way to accomplish low carbon development transformation: a bibliometric analysis during 1995-2014. Renew Sust Energ rev 68. Part 1:57-69

Weiland P (2010) Biogas production: current state and perspectives. Appl Microbiol Biot 85(4):849-860. https://doi.org/10.1007/s00253-0092246-7

Wylie R (1974) Energy-saving turbine uses wastewater to raise output. Chem Eng-New York 81(18):54-56

Xie SD, Zhang J, Ho YS (2008) Assessment of world aerosol research trends by bibliometric analysis. Scientometrics 77(1):113-130. https://doi.org/10.1007/s11192-007-1928-0

Xu Y, Boeing WJ (2013) Mapping biofuel field: a bibliometric evaluation of research output. Renew Sust Energ Rev 28:82-91
Yagub MT, Sen TK, Afroze S, Ang HM (2014) Dye and its removal from aqueous solution by adsorption: a review. Adv Colloid Interfac 209: 172-184. https://doi.org/10.1016/j.cis.2014.04.002

Yang B, Huang K, Sun D, Zhang Y (2017) Mapping the scientific research on non-point source pollution: a bibliometric analysis. Environ Sci Pollut R 24(5):4352-4366.https://doi.org/10.1007/ s11356-016-8130-y

Yataganbaba A, Ozkahraman B, Kurtbas I (2017) Worldwide trends on encapsulation of phase change materials: a bibliometric analysis (1990-2015). Appl Energ 185. Part 1:720-731

Yi Z, Ye J, Kikugawa N, Kako T, Ouyang S, Stuart-Williams H, Yang H, Cao J, Luo W, Li Z, Liu Y, Withers RL (2010) An orthophosphate semiconductor with photooxidation properties under visible-light irradiation. Nat Mater 9(7):559-564. https://doi.org/10.1038/ nmat 2780

Yiannopoulos AC, Manariotis ID, Chrysikopoulos CV (2008) Design and analysis of a solar reactor for anaerobic wastewater treatment. Bioresour Technol 99(16):7742-7749. https://doi.org/10.1016/j. biortech.2008.01.067

Yu H, Wei Y, Tang B, Mi Z, Pan S (2016) Assessment on the research trend of low-carbon energy technology investment: a bibliometric analysis. Appl Energ 184:960-970. https://doi.org/10.1016/j. apenergy.2016.07.129

Zhang G, Xie S, Ho Y (2010) A bibliometric analysis of world volatile organic compounds research trends. Scientometrics 83(2):477-492. https://doi.org/10.1007/s11192-009-0065-3

Zhang Y, Yao X, Qin B (2016) A critical review of the development, current hotspots, and future directions of Lake Taihu research from the bibliometrics perspective. Environ Sci Pollut R 23(13):1281112821. https://doi.org/10.1007/s11356-016-6856-1

Zhang Y, Zhang Y, Shi K, Yao X (2017) Research development, current hotspots, and future directions of water research based on MODIS images: a critical review with a bibliometric analysis. Environ Sci Pollut R 24(18): 15226-15239. https://doi.org/10.1007/s11356017-9107-1

Zheng T, Li P, Wang Q, Li X, Ai H, Gan K, Sharavsambuu A (2015a) Pilot-scale experiments on brewery wastewater treatment and sludge reduction based on food chain predation. Desalin Water Treat 55(5): $1142-1151$

Zheng T, Wang Q, Shi Z, Huang P, Li J, Zhang J, Wang J (2015b) Separation of pollutants from oil-containing restaurant wastewater by novel microbubble air flotation and traditional dissolved air flotation. Sep Sci Technol 50(16):2568-2577

Zheng T, Wang Q, Zhang T, Shi Z, Tian Y, Shi S, Smale N, Wang J (2015c) Microbubble enhanced ozonation process for advanced treatment of wastewater produced in acrylic fiber manufacturing industry. J Hazard Mater 287:412-420. https://doi.org/10.1016/j. jhazmat.2015.01.069

Zheng T, Wang J, Wang Q, Nie C, Smale N, Shi Z, Wang X (2015d) A bibliometric analysis of industrial wastewater research: current trends and future prospects. Scientometrics 105(2):863-882. https://doi.org/10.1007/s11192-015-1736-X

Zheng T, Zhang T, Wang Q, Tian Y, Shi Z, Smale N, Xu B (2015e) Advanced treatment of acrylic fiber manufacturing wastewater with a combined microbubble-ozonation/ultraviolet irradiation process. RSC Adv 5(95):77601-77609. https://doi.org/10.1039/ C5RA14575A

Zheng T, Wang J, Wang Q, Nie C, Shi Z, Wang X, Gao Z (2016a) A bibliometric analysis of micro/nano-bubble related research: current trends, present application, and future prospects. Scientometrics 109(1):53-71. https://doi.org/10.1007/s11192-016-2004-4

Zheng T, Wang Q, Shi Z, Zhang Z, Ma Y (2016b) Microwave regeneration of spent activated carbon for the treatment of ester-containing wastewater. RSC Adv 6(65):60815-60825. https://doi.org/10.1039/ C6RA05211H 
Zheng T, Wang Q, Shi Z, Fang Y, Shi S, Wang J, Wu C (2016c) Advanced treatment of wet-spun acrylic fiber manufacturing wastewater using three-dimensional electrochemical oxidation. J Environ Sci 50:2131. https://doi.org/10.1016/j.jes.2016.03.020

Zheng M, Fu H, Ho Y (2017) Research trends and hotspots related to ammonia oxidation based on bibliometric analysis. Environ Sci Pollut R 24(25): 20409-20421. https://doi.org/10.1007/s11356017-9711-0

Zhou P, Leydesdorff L (2006) The emergence of China as a leading nation in science. Res Policy 35(1):83-104. https://doi.org/10. 1016/j.respol.2005.08.006

Zuo J, Pullen S, Rameezdeen R, Bennetts H, Wang Y, Mao G, Zhou Z, Du H, Duan H (2017) Green building evaluation from a life-cycle perspective in Australia: a critical review. Renew Sust Energ Rev 70: 358-368. https://doi.org/10.1016/j.rser.2016.11.251

Zyoud SH, Al-Rawajfeh AE, Shaheen HQ, Fuchs-Hanusch D (2016) Benchmarking the scientific output of industrial wastewater research in Arab world by utilizing bibliometric techniques. Environ Sci Pollut Res 23(10):10288-10300. https://doi.org/10.1007/s11356016-6434-6

Zyoud SH, Fuchs-Hanusch D, Zyoud SH, Al-Rawajfeh AE, Shaheen HQ (2017) A bibliometric-based evaluation on environmental research in the Arab world. Int J Environ Sci Technol 14(4): 689-706. https:// doi.org/10.1007/s13762-016-1180-3 